
24 meridional overturning.

\title{
Deglacial Floods in the Beaufort Sea Preceded Younger Dryas Cooling
}

\author{
L.D. Keigwin ${ }^{1 *}$, S. Klotsko ${ }^{2}$, N. Zhao ${ }^{1}$, B. Reilly ${ }^{3}$, L. Giosan ${ }^{1}$, and N.W. Driscoll ${ }^{2}$
}

${ }^{1}$ Woods Hole Oceanographic Institution, Woods Hole, MA 02543.

${ }^{2}$ Scripps Institution of Oceanography, UCSD, La Jolla, CA 92093.

${ }^{3}$ College of Earth, Ocean, and Atmospheric Sciences, OSU, Corvallis, OR 97331.

*Correspondence to: 1keigwin@whoi.edu

The Younger Dryas cooling at $\sim 13 \mathrm{ka}$, after 2 kyr of postglacial warming, is a century-

old climate problem. The Younger Dryas is thought to have resulted from a slow-down of

the Atlantic meridional overturning circulation in response to a sudden flood of

Laurentide Ice Sheet meltwater that reached the Nordic Seas. Although there is no

oxygen isotope evidence in planktonic foraminifera from the open western North Atlantic

for a local source of meltwater from the Gulf of St. Lawrence where it was predicted, we

report here that the eastern Beaufort Sea contains the long-sought signal of ${ }^{18} \mathrm{O}$-depleted

water. Beginning at $\sim 12.94 \pm 0.15 \mathrm{ka}$, oxygen isotopes in planktonic foraminifera from

two sediment cores as well as sediment and seismic data indicate a flood of melt water,

ice and sediment to the Arctic via Mackenzie River that lasted about 700 years. The

minimum in oxygen isotope ratios lasted $\sim 130$ years. The floodwater would have

travelled north along the Canadian Archipelago, and through Fram Strait to the Nordic

Seas where freshening and freezing near sites of deepwater formation would have

suppressed convection, and caused the Younger Dryas cooling by reducing the

Introduction

It is known that conditions in the Arctic Ocean have a profound effect on the

North Atlantic Ocean, for example the Great Salinity Anomaly (GSA) of the 1960s and $1970 s^{1}$ and that export of excess fresh water and ice through Fram Strait was the origin of 
29 the GSA ${ }^{2,3}$. During transit of the GSA around convective regions of the Nordic Seas,

30 decreased sea surface salinities and increased sea ice cover reduced convective overturn

31 and contributed to very harsh winters. There is reason to expect that similar and even

32 larger climate events occurred in the past, especially during deglaciation when huge

33 volumes of meltwater and ice suddenly entered the Gulf of Mexico, the Arctic, and

34 Nordic Seas. For example, it was discovered several decades ago that an abrupt decrease

35 in the oxygen isotope ratio $\left(\delta^{18} \mathrm{O}\right)$ in surface-dwelling planktonic foraminifera midway

36 through deglaciation in the Gulf of Mexico was a signal of a fresh water flood ${ }^{4}$. The

37 source of this runoff must have been the decaying Laurentide Ice Sheet (LIS) via the

38 Mississippi River, but it ended abruptly at about $13 \mathrm{ka}^{5}$. Kennett and Shackleton ${ }^{4}$

39 proposed that, as the southern margin of the LIS retreated northward, meltwater was

40 routed eastward to the Gulf of St. Lawrence, and the western North Atlantic. The $\delta^{18} \mathrm{O}$

41 decrease in the Gulf of Mexico was more than $2 \%$, so a signal of $1 \%$ or more should

42 stand out in fresher, higher latitude waters. However, a low $\delta^{18} \mathrm{O}$ signal at about $13 \mathrm{ka}$ has

43 never been detected in high-quality sediment cores from the open western North

44 Atlantic $6,7,8$, yet it is believed that the diversion of the flood from the Gulf of Mexico

45 interrupted deep ocean convection and caused the well-known Younger Dryas (YD) cold

46 episode (12.9-11.7 ka) in the North Atlantic region9. Other proposed explanations for the

47 origin of the YD include melting of the Fennoscandian ice sheet ${ }^{10}$, changes in

48 atmospheric circulation ${ }^{11}$, and a combination of ice sheet melting, atmospheric flow

49 patterns, and radiative forcing ${ }^{12}$. However, those explanations beg the question where

50 did the diverted meltwater go. 
51 The YD was discovered near the beginning of the $20^{\text {th }}$ Century as one of several

52 appearances of the Arctic wildflower Dryas octopetala in postglacial deposits in

53 Scandinavia ${ }^{13,14}$ and eventually was defined as a useful chronostratigraphic zone in the

54 North Atlantic region ${ }^{15}$. It was later proposed that meltwater routing and drainage pattern

55 changes could have caused the YD by lowering surface ocean salinity ${ }^{16,17}$.

56 Recently, a glacial systems model showed that fresh water stored in glacial Lake

57 Agassiz most likely traveled north to the Beaufort Sea via Mackenzie River at $13 \mathrm{ka}^{18}$,

58 and extensive field work on the Mackenzie Delta identified clear evidence of massive

59 flood deposits that occurred about the same time ${ }^{19}$. Although the exact timing and

60 magnitude of the Murton et al. ${ }^{19}$ conclusions have been questioned ${ }^{20}$, application of a

61 high resolution ocean circulation model ${ }^{21}$ showed that, only when released to the Arctic

62 Ocean (via Mackenzie River), could the Lake Agassiz flood have caused the Younger

63 Dryas reduction of Atlantic meridional overturning circulation (AMOC) $)^{22}$ and

64 consequent northern hemisphere cooling.

Results and Discussion

66 Here we present data that show two events of substantial sea surface freshening

67 during deglaciation in newly acquired large diameter (jumbo) piston cores (JPCs) from

$68690 \mathrm{~m}$ on the continental slope $\sim 100 \mathrm{~km}$ east of Mackenzie River (JPCs 15 and 27, Fig.

69 1). These and other new cores underlie the Atlantic water that enters the Arctic at Fram

70 Strait and the Barents Sea in the depth range $\sim 100$ to $800 \mathrm{~m}$ and circulates counter-

71 clockwise along the continental slopes ${ }^{23}$. JPC-15 penetrated $\sim 13 \mathrm{~m}$ of sediment and was

72 probably stopped by a coarse ice rafted debris (IRD) layer that has high magnetic

73 susceptibility, high Ca content (Fig. 2), and makes a prominent reflector in the acoustic 
74 stratigraphy across the region (Fig. 3). Later, reoccupying the same site, a longer

75 (heavier) deployment (JPC-27) penetrated the deeper coarse layer. As these cores have

76 nearly identical lithology, we spliced them together to make a composite JPC-15/27 (Fig.

77 Extended Data (ED)1).

78 Compared to the lower layer, the upper coarse layer at this site is thicker, has

79 multiple events, and fewer IRD grains (Fig. 2), but each layer also has finer sand and silt

80 (Fig. 3). These data indicate that each coarse layer provides a record of enhanced

81 sediment transport to the upper slope of the Beaufort Sea. The two main events must be

82 the same that Scott et al. ${ }^{24}$ noted in Canadian core PC-750 (Fig. 1). X-ray fluorescence

83 (XRF) counts of calcium (interpreted as detrital $\mathrm{CaCO}_{3}$ content) show that our two events

84 have similar carbonate content, but also that lowest carbonate delivery to the region

85 occurred before the oldest event and was only a little higher between the events (Fig. 2).

86 Sediment deeper than $\sim 5 \mathrm{~m}$ is faintly laminated at the $\mathrm{cm}$ scale, except for the massive

87 appearance of the first event (13.0-13.5 m). Laminae are better developed between 6 and

$8812 \mathrm{~m}$, where about 300 were counted in XRF data (Fig. ED2).

89 As with the sediment and geophysical data, $\delta^{18} \mathrm{O}$ on the polar planktonic

90 foraminifer Neogloboquadrina pachyderma (Ehrenberg) left coiling (Nps) in JPC-15/27

91 is marked by two prominent events at the same depths in the core (Fig. 2). At those

92 levels $\delta^{18} \mathrm{O}$ of $\mathrm{Nps}\left(\delta^{18} \mathrm{O} \mathrm{Nps}\right)$ decreased at least $1.0 \%$ below the $\sim 2.0 \%$ baseline that

93 extends $>4 \mathrm{~m}$ down the core. Above a pronounced maximum in $\delta^{18} \mathrm{O}_{\mathrm{Nps}}$ at $2-3 \mathrm{~m}$, values

94 decrease by $\sim 2.0 \%$ to the core top. We find the upper $\delta^{18} \mathrm{O}_{\mathrm{Nps}}$ minimum to the west of

95 JPC15/27 at JPC-09 (see ED), but not at other cores farther west (Figure 1). Benthic

96 foraminiferal (Cassidulina neoteretis Seidenkrantz) $\delta^{18} \mathrm{O}$ at JPC15/27 yields a 
97 stratigraphy more typical of the world ocean, with generally increasing values down the

98 core, although they are consistently low at about $5 \mathrm{~m}$ in the same samples where $\delta^{18} \mathrm{O}_{\mathrm{Nps}}$

99 is low (Fig. 2E).

101 Chronology in Arctic sediments is uncertain because, although radiocarbon dating

102 of foraminifera is the simplest method, at present there is no way to know exactly the

103 near surface reservoir correction $(\Delta \mathrm{R})$ in the past. We made 14 accelerator mass

104 spectrometer (AMS) ${ }^{14} \mathrm{C}$ measurements on Nps from core 15 (Table ED1). Those dates

105 indicate maximum rates of sedimentation of at least $10 \mathrm{~m}$ per $1000{ }^{14} \mathrm{C}$ yrs between 6 and

$10612 \mathrm{~m}$ in the mid-deglacial interval of the core (Fig. 2F, ED3). Before and after that mid-

107 core extreme, rates are half that or less. We assume Nps calcified near the interface

108 between fresher, near-surface water and underlying saltier water, as it does today ${ }^{25}$. In

109 that environment it was salty enough to survive but shallow enough to capture low $\delta^{18} \mathrm{O}$

110 events. Six of the Nps dates were paired with dates on C. neoteretis. On average,

111 benthics are only $120 \pm 220$ yrs older than planktonics, including a result from $1300 \mathrm{~m}$ in

112 the Chukchi Sea (HLY0205 JPC-16, Fig. 1) ${ }^{26}$. This small difference indicates upper

113 slope waters were relatively well ventilated.

114 For a calendar (calibrated) ${ }^{14} \mathrm{C}$ chronology, we need to choose a $\Delta \mathrm{R}$. In the

115 modern Arctic the Pacific inflow through Bering Strait is a source of old carbon that

116 would have been absent prior to about 11 ka when the strait was dry land ${ }^{26,27}$ (see Fig.

117 ED4 and further discussion). Bondevik et al. ${ }^{28}$ showed that surface waters along the

118 Norwegian coast, which would have fed the Arctic, had a $\Delta \mathrm{R}$ of about $0 \mathrm{yrs}$, like today,

119 during the Bølling-Allerød (B/A), about 100 yrs early in the YD, and about $200 \mathrm{yrs}$ 
120 during the mid-YD. Cao et al. ${ }^{29}$ reached a similar conclusion based on $\mathrm{U}$ series dates and

$121{ }^{14} \mathrm{C}$ measurements on a solitary coral from the southern Labrador Sea, which would

122 monitor intermediate depth waters leaving the Nordic Seas. Therefore, we developed an

123 age model using a Bayesian method and $\Delta \mathrm{R}=0 \pm 100$ yrs for the Holocene and the

124 Allerød, and $200 \pm 100$ yrs for the YD (Fig. ED5). If the relatively high $\Delta \mathrm{R}$ during the

125 YD was triggered by an event late in the Allerød, then the onset of that event should be

126 calibrated with a $\Delta \mathrm{R}$ of $\sim 0$ years

127 These estimates of only a modest $\Delta \mathrm{R}(0-200$ years) encompass the pre-bomb

128 estimate ${ }^{30}$ based on ${ }^{14} \mathrm{C}$, tritium, and $\delta^{18} \mathrm{O}$ on samples collected decades ago when bomb

129 produced nuclides were beginning to invade the deep Arctic. Ostlund et al.$^{30}$ inferred the

130 pre-bomb ${ }^{14} \mathrm{C}$ activity of waters between 500 and $1500 \mathrm{~m}$ was about $-55 \pm 5 \%$, giving a

$131 \Delta \mathrm{R}$ of $\sim 40$ yrs (Fig. 4). Therefore, although deep-water ${ }^{14} \mathrm{C}$ circulation in the Arctic may

132 have been very different in the past ${ }^{31,32}$, it appears that the ${ }^{14} \mathrm{C}$ ventilation of upper waters

$133(<1500 \mathrm{~m})$ in the Canada Basin was similar to today.

134 Our age model gives interpolated calendar ages in JPC-15/27 of $12.94 \pm 0.15 \mathrm{ka}$

135 for the onset of the upper $\delta^{18} \mathrm{O}$ minimum (constrained by dates of $13.06 \mathrm{ka}$ at $520 \mathrm{~cm}$ and

$13612.66 \mathrm{ka}$ at $500 \mathrm{~cm}$; Table ED1), and $\sim 14.6 \mathrm{ka}$ for the peak of the older one (Fig. 5). The

137 age of the older event and its associated IRD is consistent with the ages (15.2-14.1 ka)

138 reported for the initial withdrawal of ice streams from Amundsen Gulf and M'Clure

139 Strait $^{33}$. The age for the onset of the later freshening in the Beaufort Sea $(12.94 \pm 0.15$

$140 \mathrm{ka}$ ) is virtually the same as the beginning of the Younger Dryas at $12.85 \pm 0.14 \mathrm{ka}$ in

141 Greenland ice cores ${ }^{34}$, and identical to the end of freshening in the Gulf of Mexico (12.94

$142 \pm 0.17$ ka) (Fig. 5). Minimum $\delta^{18} \mathrm{O}$ in JPC-15/27 first occurred at $12.59 \pm 0.14 \mathrm{ka}$, within 
143 uncertainty of the equivalent event at JPC-09 $(12.7 \pm 0.10 \mathrm{ka})$. The coincidence of the

144 end of flooding in the Gulf of Mexico and the onset of flooding in the eastern Beaufort

145 Sea is strongly suggestive that the routing of meltwaters ${ }^{35}$ switched from the Gulf of

146 Mexico to the Beaufort Sea at about $13 \mathrm{ka}$.

Ocean and climate change in Beaufort Sea

148 Our composite sequence from the continental slope east of Mackenzie River

149 began around 15-16 ka with modest ice rafting from local sources such as ice streams in

150 M'Clure Strait and Amundsen Gulf. Icebergs would have traveled clockwise around

151 Canada Basin via the Beaufort Gyre, and the counter clockwise shelfbreak current ${ }^{36}$

152 would have been weakened with sea level below the depth of Bering Strait. Mackenzie

153 River may not have supplied substantial detrital carbonate because the extensive

154 Devonian carbonate terrain south of Great Slave Lake and north of Ft. McMurray ${ }^{37}$ was

155 probably ice-covered, but it may have been a source of runoff and sediment at least since

$156 \sim 18 \mathrm{ka}$ based on the background low $\delta^{18} \mathrm{O}$ (Fig. 5). This was a time when secular change

157 in the ocean due to increased ice volume was about $+1 \%$, indicating the sea surface was

158 less saline than today by at least $1 \mathrm{psu}$, assuming the modern $\delta^{18} \mathrm{O}$-salinity relationship ${ }^{38}$.

159 This setting prevailed until $\sim 14.6 \mathrm{ka}$, when ice rafting dramatically increased from

160 Amundsen Gulf and $\mathrm{M}^{\prime}$ Clure Strait, and $\delta^{18} \mathrm{ONps}_{\mathrm{Np}}$ decreased by $>1 \%$. The five samples

161 defining this minimum were probably deposited within decades.

162 At the end of the $14.6 \mathrm{ka}$ event, Amundsen Gulf probably remained a source of

163 sediment to the continental slope in the eastern Beaufort Sea until the ice stream was

164 fully retreated. Mackenzie River may have always been a large source of sediment, but

165 as more of its watershed north of Fort McMurray was deglaciated, the more important it 
166 must have become. The laminated sediments, high sedimentation rate, and general lack of

167 coarse particle ice rafting suggest large sediment input from the Mackenzie River

168 between 13.5 and $\sim 14.4 \mathrm{ka}$ (6-12 $\mathrm{m}$ in the core). The high sedimentation rates along the

169 slope may be explained by discharge over bottom fast ice on the shelf, which could

170 efficiently transport sediment farther seaward (e.g., ref 39). Based on the diagnostic

171 acoustic signature of the rapidly emplaced Bølling-Allerød section (Fig. 3), the western

172 extent of the deposit pinches out between JPC-09 and JPC-06 (Fig. 1, Fig. ED8). Counts

173 of $\sim 300$ layers within the $\sim 900$ year interval where sedimentation rates are highest show

174 the layers are probably not annual (Fig. ED2). The interval between the two $\delta^{18} \mathrm{O}_{\mathrm{Nps}}$

175 minima represents most of the Bølling-Allerød climate warming, when the AMOC was

176 almost as strong as today ${ }^{22}$, but evidently the lowered salinity in the Beaufort Gyre had

177 little direct influence on North Atlantic overturning. This may indicate that the gyre was

178 in a mostly anticyclonic state, which today stores ice and fresh water ${ }^{40}$.

179 Close to $13 \mathrm{ka}$ the rapid increase in magnetic susceptibility and decreased $\delta^{18} \mathrm{O}_{\mathrm{Nps}}$

180 in JPC-15/27 herald the beginning of the YD. Although the two $\delta^{18} \mathrm{O}_{\mathrm{Nps}}$ minima in this

181 core are similar in size, the YD event was more likely to have been a flood of fresh water

182 with high suspended load ${ }^{19}$ because $\delta^{18} \mathrm{O}$ of $C$. neoteretis, living at the seafloor, decreased

183 in exactly the same samples as Nps during the $\sim 13$ ka but not the earlier event. This, we

184 propose, may record a hyperpycnal flow that brought low salinity to the seafloor and that

185 would be more likely from a river flood. The major sediment depocenter in this model

186 must be farther seaward because sedimentation rates drop during this time interval at 690

$187 \mathrm{~m}$ water depth (Fig. 2). The YD flood can be traced to the west as far as core JPC-09

188 using $\delta^{18} \mathrm{O}_{\mathrm{Nps}}$, but the signal is not clear west of that at JPC-06, and neither the $\delta^{18} \mathrm{O}$ 
189 minima nor the maximum in magnetic susceptibility are evident as far west as JPC-02

190 near Barrow, Alaska (Fig. ED7).

191 About 200 yrs after the onset of the YD flood all four sediment and isotope

192 proxies were briefly aligned in the first (labeled "a") of several sub-events (Fig. 2 A-D).

193 The low $\delta^{18} \mathrm{O}_{\mathrm{Nps}}$ episode is mostly centered between the subpeaks "a" and "b" of the

194 magnetic susceptibility ( 12.8 to $12.3 \mathrm{ka}$ ), but the last of the spikes in IRD and carbonate

195 deposition ended with increased $\delta^{18} \mathrm{O}_{\mathrm{Nps}}$ at the end of flooding. Maximum $\delta^{18} \mathrm{O}_{\mathrm{Nps}}$ at

$196 \sim 12.2$ ka probably marks an interval of relatively high salinity in the near surface

197 Beaufort Sea ${ }^{41}$, followed by more typical decreasing $\delta^{18} \mathrm{O}$ trends in benthic and

198 planktonic foraminifera as ice volume decreased and climate warmed during the

199 Holocene. The lingering high magnetic susceptibility late in the YD may indicate

200 evolving sources of sediment from Mackenzie River, and it might also relate to evidence

201 of a second flood $\sim 11 \mathrm{ka}$ (ref. 19).

202 Knowing the duration of the YD flood is important for calculating the fresh water

203 transport and evaluating its effect on the AMOC. If we take the main flood interval of

204 the $\mathrm{YD}$ as that part where $\delta^{18} \mathrm{O}_{\mathrm{Nps}}$ was less than the $2 \%$ baseline, then it lasted $\sim 660$

205 years. If the lowest $\delta^{18} \mathrm{O}_{\mathrm{Nps}}$ indicates peak discharge, then most of the fresh water

206 transport could have occurred in about 130 years (Table ED3). However, it must be kept

207 in mind that if the Mackenzie River choke point at Fort McMurray was breached

208 suddenly at the beginning of the $\mathrm{YD}$, and this is contentious ${ }^{42}$, then the outburst of

209 Glacial Lake Agassiz water would have probably produced initial salinities over our core

210 site that were too low for Nps to grow. Furthermore, estimates of very high fresh water

211 transport during the flood are based on the assumption that it occurred on the timescale of 
212 a year ${ }^{43}$, yet if the main flood was that brief then it is unlikely enough planktonic

213 foraminifera could have recorded the low $\delta^{18} \mathrm{O}$ to leave a signal in the geological record.

214 Most likely the initial Mackenzie discharge at 12.9 ka was a combination of both

215 a routing change from the Gulf of Mexico and an outburst flood from glacial Lake

216 Agassiz. This potent combination of two sources of fresh water was probably effective in

217 reducing the $\mathrm{AMOC}^{35}$, especially considering it was an Arctic source ${ }^{21}$. However, even

218 if the combined routing plus glacial lake release to Mackenzie River itself was too

219 modest to trigger a collapse of the AMOC, many large rivers empty into the $\mathrm{Arctic}^{2}$, and

220 Lena River, one of the largest, also flooded about $13 \mathrm{ka}$ (ref 44). Finally, it should be

221 noted that in addition to fresh water floods in the Arctic around the beginning of the YD,

222 it is reported that enhanced sea ice export through Fram Strait at that time also had a

223 Beaufort Sea source ${ }^{45}$.

224 By the onset of the YD, the AMOC may have already been close to a tipping

225 point after $\sim 1500$ years of low salinity leakage from the Beaufort Sea, and transport to the

226 nearshore convective regions of the Nordic seas ${ }^{46,47}$. Increased freshening has also been

227 noted at other coastal locations in the North Atlantic, including the proposed eastern

228 outlet (St. Lawrence River system) using various proxies ${ }^{48,49,50}$, the Baltic Sea ${ }^{10,51}$, and

229 off eastern Greenland where $\delta^{18} \mathrm{O}_{\mathrm{Nps}}$ minima of YD age are thought to reflect local

230 melting ${ }^{52}$ but could also be evidence of the Mackenzie flood. The coincidence of

231 decreased $\delta^{18} \mathrm{O}$ in the Beaufort Sea and increased $\delta^{18} \mathrm{O}$ in the Gulf of Mexico near the

232 beginning of the YD is a good test of the meltwater diversion hypothesis of Kennett and

233 Shackleton ${ }^{4}$ (Fig. 5). Considering all the other observations, including the climatic

234 background suggested by alternative hypotheses ${ }^{10-12}$ that may have helped sustained the 
235 event, and the lack of a large YD minimum in $\delta^{18} \mathrm{O}$ anywhere in the open North Atlantic

236 Ocean, the $\sim 12.9$ ka flood of Mackenzie River was most likely the trigger for the

237 reduction of the AMOC and Younger Dryas cooling.

238

References

239 1. Dickson, R. R., Meincke, J., Malmberg, S. A. \& Lee, A. J. The "Great Salinity

240 Anomaly" in the Northern North Atlantic 1968-1982. Prog. Oceanog. 20, 103-

$241 \quad 151(1988)$.

242 2. Aagard, K. \& Carmack, E. The role of sea ice and other fresh water in the Arctic

243 circulation. Jour. Geophys. Res. 94, 14485-14498 (1989).

244 3. Häkkinen, S. An Arctic source for the great salinity anomaly: A simulation of the

245 Arctic ice-ocean system for 1955-1975. Jour. of Geophys. Res. 98, 16,397-

$246 \quad 316,410$ (1993).

247 4. Kennett, J. P. \& Shackleton, N. J. Laurentide ice sheet meltwater recorded in Gulf of $248 \quad$ Mexico deep-sea cores. Science 188, 147-150 (1975).

249 5. Williams, C., Flower, B. \& Hastings, D. W. Seasonal Laurentide ice sheet melting

250 during the "Mystery Interval" (17.5-14.5 ka). Geology 40, 955-958 (2012).

251 6. Keigwin, L. D. \& Jones G. A. The marine record of deglaciation from the continental

252 margin off Nova Scotia. Paleoceanography 10, 973-985 (1995).

253 7. de Vernal, A., Hillaire-Marcel, C. \& Bilodeau, G. Reduced meltwater outflow from

254 the Laurentide ice margin during the Younger Dryas. Nature 381, 774-777

$255 \quad$ (1996). 
256 8. Keigwin, L. D., Sachs, J., Rosenthal, Y. \& Boyle, E. A. The 8200 year B.P. event in the 257 slope water system, western subpolar North Atlantic. Paleoceanography 20, 258 doi:10.1029/2004PA001074 (2005).

259 9. Broecker, W. S., et al. The routing of meltwater from the Laurentide ice-sheet 260 during the Younger Dryas cold episode. Nature 341, 318-321 (1989).

261 10. Muschitiello, F. et al. Fennoscandian freshwater control on Greenland 262 hydroclimate shifts at the onset of the Younger Dryas. Nature Comm. (2015).

263 11. Brauer, A. Haug, G.H., Dulski, P., Sigman, D. M., \& Negendank, J. F. W. An abrupt 264 wind shift in western Europe at the onset of the Younger Dryas cold period. 265 Nature Geoscience 1:520-523 (2008).

266 12. Renssen, H. et al. Multiple causes of the Younger Dryas cold period. Nature $267 \quad$ Geoscience 8, 946-950 (2015).

268 13. Andersson, G. Swedish vegetation history. Stockholm, P.A. Norstedt \& Soners $269 \quad$ Forlag (1897).

270 14. Hartz, N. \& Milthers, V. The late glacial clay in the Allerod brickyard. Meddelelser 271 Dansk Geologisk Foreningen 8, 31-60 (1901).

272 15. Mangerud, J., Andersen, S. T., Berglund, B. E., \& Donner, J. J. Quaternary 273 stratigraphy of Norden, a proposal for terminology and classification. Boreas $274 \quad 3,110-127(1974)$.

275 16. Johnson, R. G. \& McClure B. T. A model for northern hemisphere continental ice 276 sheet variation. Quaternary Res. 6, 325-353 (1976).

277 17. Rooth, C. Hydrology and ocean circulation. Prog. Oceanog. 11, 131-149 (1982). 
278 18. Tarasov, L. \& Peltier, W. R. Arctic freshwater forcing of the Younger Dryas cold reversal. Nature 435, 662-665 (2005).

280 19. Murton, J. B., Bateman, M. D., Dallimore, S. R., Teller, J. T. \& Yang, Z. Identification 281 of Younger Dryas outburst flood path from lake Agassiz to the Arctic Ocean. Nature 464, 740-743 (2010).

283 284 285

20. Carlson, A.E. et al. Geochemical proxies of North American freshwater routing during the Younger Dryas cold event. Proc. Nat. Acad. Sci. 104, 6556-6561 (2007).

21. Condron, A. \& Winsor, P. Meltwater routing and the Younger Dryas. Proc. Nat. Acad. Sci. doi:10.1073/pnas.1207381109 (2012).

22. McManus, J. F., Francois, R., Gherardi, J.-M., Keigwin, L. D. \& Brown-Leger, S. Collapse and rapid resumption of Atlantic meridional circulation linked to deglacial climate changes. Nature 428, 834-837 (2004).

23. Rudels, B., Jones, E. P., Anderson, L. G. \& Kaattner, G. On the intermediate depth waters of the Arctic Ocean. Geophysical Monograph 85, 33-46 (1994).

24. Scott, D., Schell, T., St-Onge, G., Rochon, A. \& Blasco, S. Foraminiferal assemblage changes over the last 15,000 years on the Mackenzie-Beaufort Sea slope and Amundsen Gulf, Canada: Implications for past sea ice conditions. Paleoceanography 24 (doi:10.1029/2007PA001575) (2009).

25. Bauch, D., Carstens, J, \& Wefer, G. Oxygen isotope composition of living Neogloboquadrina pachyderma (sin.) in the Arctic Ocean. Earth Planet. Sci. Lett. 146, 47-58 (1997). 
300

301

302 303

26. Keigwin, L. D, Donnelly, J. P., Cook, M.S., Driscoll, N.W. \& Brigham-Grette, J. Flooding of Bering Strait and Holocene climate in the Chukchi Sea. Geology 34, 861-864 (2006).

27. Jakobsson, M. et al. Post-glacial flooding of the Beringia Land Bridge dated to 11,000 cal yrs BP based on new geophysical and sediment records. Clim. Past Discuss., doi:10.5194/cp-2017-11 (2017).

28. Bondevik, S., Mangerud, J., Birks, H. H., Gulliksen, S. \& Reimer, P. Changes in North Atlantic radiocarbon reservoir ages during the Allerod and Younger Dryas. Science 312, 1514-1517 (2006)

29. Cao, L., Fairbanks, R.G., Mortlock, R.A. \& Risk M.A. Radiocarbon reservoir age of high latitude North Atlantic surface water during the last deglacial. Quat. Sci. Rev. 26, 732-742 (2007).

30. Ostlund, H., Possnert, G. \& Swift, J. Ventilation rate of the deep Arctic Ocean from carbon 14 data. Jour. Geophys. Res: 92, 3769-3777 (1987).

31. Cronin, T. et al. Deep Arctic Ocean warming during the last glacial cycle. Nature Geoscience 5, 631-634 (2012).

32. Thornalley, D. J. R. et al. A warm and poorly ventilated deep Arctic Mediterranean during the last glacial period. Science 349, 706-710 (2015).

33. Stokes, C. R., Clark, C. D. \& Storrar, R. Major changes in ice stream dynamics during deglaciation of the north-western margin of the Laurentide ice sheet. Quat. Sci. Rev. 28, 721-738 (2009).

34. Rasmussen, S., et al. A new Greenland ice core chronology for the last glacial termination. Jour. Geophys. Res. 111, doi:10.1029/2005JD006079 (2006). 
323 35. Meissner, K. \& Clark, P. Impact of floods versus routing events on the

324 thermohaline circulation. Geophys. Res. Lett. 33, doi:10.1029/2006GL026705

$325 \quad$ (2006).

326 36. von Appen, W.-J. \& Pickart, R. Two configurations of the western Arctic

327 Shelfbreak Current in summer. Jour. Phys. Oceanography 42, 329-351 (2012).

328 37. Wheeler, J., et al. Geological Map of Canada. "A" Series Map 1860A;

329 doi:10.4095/208175, Geological Survey of Canada (1996).

330 38. Cooper, L., et al. Linkages among runoff, dissolved organic carbon, and the stable

331 oxygen isotope composition of seawater and other water mass indicators in

332 the Arctic Ocean. Jour. Geophys. Res. 110, (doi:10.1029/2005JG000031)

$333 \quad$ (2005).

334 39. Macdonald, R. \& Yu, Y. The Mackenzie estuary of the Arctic OCean. Handbook of

335 Environmental Chemistry. Berlin, Springer-Verlag. 5: 91-120 (2006).

336 40. Proshutinsky, A. \& Johnson, M.A. Two circulation regimes of the wind-driven

337 Arctic Ocean. Jour. Geophys. Res. 102,12493-12514 (1997).

338 41. Schell, T., Scott, D. B., Rochon, A. \& Blasco, S. Late Quaternary paleoceanography

339 and paleo-sea ice conditions in the Mackenzie Trough and Canyon, Beaufort

$340 \quad$ Sea. Can. J. Earth Sci. 45, 1399-1415 (2008).

341 42. Fisher, T.G., Waterson, N., Lowell, T. V. \& Hajdas, I. Deglaciation ages and

342 meltwater routing in the Fort McMurray region, northeastern Alberta and

343 northwestern Saskatchewan, Canada. Quat. Sci. Rev. 28, 1608-1624 (2009). 
344 43. Leverington, D. W., Mann, J. D. \& Teller, J. T. Changes in the bathymetry and 345 volume of glacial Lake Agassiz between 11,000 and $9300{ }^{14} \mathrm{C}$ yr B.P. 346 Quaternary. Res. 54, 174-181 (2000).

347 44. Spielhagen, R.F., Erlenkeuser, H. \& Siegert, C. History of freshwater runoff across 348 the Laptev Sea (Arctic) during the last deglaciation. Global and Planetary $349 \quad$ Change 48, 187-207 (2005).

350 45. Hillaire-Marcel, C., Maccali, J., Not, C. \& Poirier, A. Geochemical and isotopic 351 tracers of Arctic sea ice sources and export with special attention to the $352 \quad$ Younger Dryas interval. Quat. Sci. Rev. 79, 184-190 (2013).

353 46. Mauritzen, C. Production of dense overflow waters feeding the North Atlantic 354 across the Greenland-Scotland Ridge. Part 1: Evidence for a revised 355 circulation scheme. Deep-Sea Res. 43, 769-806 (1996).

356 47. Pedlosky, J. \& Spall, M. Boundary intensification of vertical velocity in a beta357 plane basin. Jour. Phys. Oceanography 35, 2487-2500 (2005).

358 48. Carlson, A.E. \& Clark, P.U. Ice sheet sources of sea level rise and freshwater 359 discharge during the last deglaciation. Rev. Geophys $\mathbf{5 0}$ (2011RG000371) $360 \quad$ (2012).

361 49. Cronin, T.M., Rayburn, J.A., Guilbault, J.-P. \& Thunell, R. Stable isotope evidence 362 for glacial lake drainage through the St. Lawerence estaury, eastern Canada, $363 \sim 13.1-12.9$ Ka. Quat. International 260, 55-65 (2012).

364 50. Levac, E., Lewis, M., Stretch, V., Duchesne, K. \& Neulieb, T. Evidence for 365 meltwater drainage via the St. Lawrence River valley in marine cores from 
the Laurentian Channel at the time of the Younger Dryas. Global and Planetary Change 130, 47-65 (2015).

368 51. Boden, P., Fairbanks, R.G., Wright, J. D. \& Burckle, L. H. High-resolution stble 369 isotope records from southwest Sweden: The drainage of the Baltic Ice Lake and Younger Dryas ice margin oscillations. Paleoceanography 12, 39-49 (1997).

372 52. Jennings, A.E, Hald, M., Smith, M. \& Andrews, J.T. Freshwater forcing from the 373 Greenland Ice Sheet during the Younger Dryas: evidence from southeastern Greenland shelf cores. Quat. Sci. Rev. 25, 282-298 (2006).

53. Jakobsson, M. et al. The International bathymetric chart of the Arctic Ocean (IBCAO) version 3.0. Geophys. Res. Lett. Doi: 10.1029/2012GL052219 (2012).

378 54. Leventer, A., Williams, D. F. \& Kennett, J. P. Dynamics of the Laurentide ice sheet 379 during the last deglaciation: evidence from the Gulf of Mexico. Earth and Planet. Sci. Lett. 59,11-17 (1982).

382 Acknowledgements We thank the officers and crew of USCGC Healy for making this 383 project a success. We are also indebted to M. Carman for help processing core samples;

384 A. McNichol for helpful discussions of ${ }^{14} \mathrm{C}$ in the Arctic; A. Gagnon for the stable 385 isotope measurements; the NOSAMS staff for providing ${ }^{14} \mathrm{C}$ data; $\mathrm{M}$. McCarthy, C.

386 Moser, C. Griner, and C. Mayo for leading the coring effort. S. Nielsen helped with

387 translation of ref. 14. The manuscript benefited from comments of 4 anonymous 388 reviewers and help from M. Blaauw and B. Keigwin with the Bayesian age model. This 
390 N.W.D.

391

392 Author Contributions L.D.K. conceived the project, N.W.D. and S.K surveyed the

393 seafloor, identified coring locations, and studied grain size; B.R. conducted the magnetic

394 measurements; and N.Z. and L.G. conducted the XRF scanning. All authors helped write

395 the manuscript.

396 Author Information Reprints and permissions information is available at www.

397 nature.com/reprints. The authors have no competing financial interests. Correspondence

398 and requests for materials should be addressed to $\underline{1 \text { keigwin@whoi.edu }}$

$$
\text { Methods }
$$

400 Site survey methods, laminae counting methods, core sampling and stable isotope

401 methods, sample preparation for radiocarbon dating, and Bayesian age modeling

402 are presented in Supplementary Information sections 1, 2, 3, 4.2, and 4.4.

403 Data Availability:

404 Radiocarbon data appear in Extended Data Table 1, and stable isotope data appear

405 in Extended Data Table 3. The Fe/Ca and magnetic data are available from the

406 authors upon request.

407 Code availability:

408

409 The code for the bacon age model is freely available;

410 see http://chrono.qub.ac.uk/blaauw/bacon.html. The settings used are found in

411 Supplementary Section 4.4. 
414 Fig. 1. Overview of core locations and stratigraphy in the eastern Beaufort Sea. (Top)

415 Track of USCGC Healy cruise 1302 with location of JPC sites (yellow) and other cores

416 (red) discussed in this study. Inset (based on ref 27) shows the study area with respect to

417 the Arctic Ocean. $\mathrm{LR}=$ Lomonosov Ridge, $\mathrm{CB}=$ Chukchi Borderland, $\mathrm{BC}=\mathrm{Barrow}$

418 Canyon, $\mathrm{MT}=$ Mackenzie Trough, $\mathrm{AG}=$ Amundsen Gulf, $\mathrm{MS}=\mathrm{M}$ 'Clure Strait, $\mathrm{BI}=\mathrm{Banks}$

419 Island, VI=Victoria Island. Based on low $\delta^{18} \mathrm{O}_{\mathrm{Nps}}$ and seismic evidence, the YD flood

420 deposit (sites in yellow with a cross) ranges from JPC-09 in the west to JPC-22 in the

421 east. Because of Coriolis force and lowered sea level, the flood would have travelled

422 north and east. (Bottom) Down core magnetic susceptibility is shown delineating the

423 Holocene (yellow) - Deglacial (blue) boundary. Selected AMS ${ }^{14} \mathrm{C}$ dates are calibrated

424 ka.

425

426 Fig. 2. Proxy data from JPC-15/27 in the eastern Beaufort Sea. Magnetic susceptibility

427 (A), lithic particle abundance (B), Ca content (proxy for $\left.\mathrm{CaCO}_{3}\right)(\mathrm{C})$, and $\delta^{18} \mathrm{O}_{\mathrm{Nps}}(\mathrm{D})$ all

428 exhibit extreme values early the Bolling/Allerod warming at $14.6 \mathrm{ka}(\mathrm{red}$ line at $1300 \mathrm{~cm})$

429 and during the YD $(11.7-12.9 \mathrm{ka})(\sim 380-510 \mathrm{~cm})$. Dashed vertical lines correlate smaller

430 features. Dashed horizontal line in (D) is a $\sim 2.0 \%$ reference for $\delta^{18} \mathrm{O}$ features. Data

431 corresponding to a large dropstone at $1346-1355 \mathrm{~cm}$ excluded from C. The C. neoteretis

432 (benthic) $\delta^{18} \mathrm{O}(\mathrm{E})$ is unremarkable except that the clear minimum $\sim 450-500 \mathrm{~cm}$ occurs in

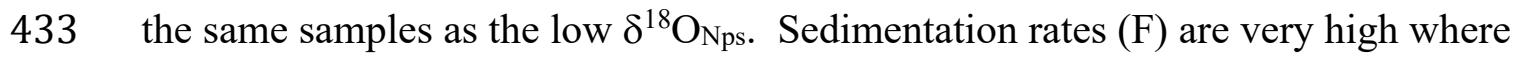

434 sediments are laminated, although ${ }^{14} \mathrm{C}$ dates exaggerate the $\mathrm{B} / \mathrm{A}$ maximima (Figure 435 ED2), 
437 Fig. 3. Grain size variability down composite jumbo piston core JPC15/27. Magnetic

438 susceptibility data are superposed on the grain size and the seismic data, assuming the

439 pressure wave velocity of the core logged at sea $\left(1333 \mathrm{~ms}^{-1}\right)$. These properties all vary

440 together. The seismic data show a diagnostic reflector pattern with an upper ( $380-520$

$441 \mathrm{~cm})$ and lower high $(\sim 1320 \mathrm{~cm})$ amplitude reflectors that bound a region of lower

442 acoustic reflectivity. The zone of lower reflectivity correlates with high sediment

443 accumulation rates, low magnetic susceptibility, low ice rafted debris (IRD), and low Ca

444 content (Fig. 2).

445

446 Fig. 4. Radiocarbon basis for the age model in this paper. Ostlund et al. ${ }^{30}$ synthesized $447 \Delta^{14} \mathrm{C}, \delta^{18} \mathrm{O}$, and tritium data collected from several Arctic ice camps (LOREX, CESAR, 448 AIWEX) between 1977 and 1985 and concluded that the pre-bomb value of intermediate 449 depth waters (500 to $1500 \mathrm{~m}$ ) was $-55 \pm 5 \%$ (vertical black line $\pm 1 \sigma$ (dashed)), and pre450 bomb shelf water was $-48 \pm 3 \%$ (triangle). The ice camp results are considered to be

451 equivalent to Canada Basin water in that all are on the west side of Lomonosov Ridge.

452 Our age model uses $\Delta \mathrm{R}=0 \pm 100(1 \sigma)$ for the Holocene and Bolling/Allerod, within

453 uncertainty of the pre-bomb estimate ${ }^{30}$, but we use a larger $\Delta R$ for the YD $(200 \pm 100)$

454 (Fig. ED5).

455

456 Fig. 5. Comparison of deglacial $\delta^{18} \mathrm{O}$ between Orca Basin in the Gulf of Mexico and 457 Beaufort Sea. Arctic data are based on N. pachyderma (s) (blue squares, core 15/27; red 458 line, JPC-09) and Orca Basin data are based on the planktonic foraminifer 
459 Globigerinoides ruber (green line, Williams et al. ${ }^{5}$; black squares, Leventer et al..$^{54}$ ) (see

460 ED for chronology details of the Leventer et al. core). The eastern Beaufort Sea

461 freshened at about 12.9 ka coincident with the end of Gulf of Mexico freshening and

462 consistent with the hypothesis that meltwater was diverted from the Gulf to a more

463 northern outlet as deglaciation progressed ${ }^{4} . \mathrm{YD}=$ Younger Dryas, $\mathrm{B} / \mathrm{A}=$ Bolling/Allerod,

464 HS-1 = Heinrich Stadial 1, LGM = last glacial maximum.

465 

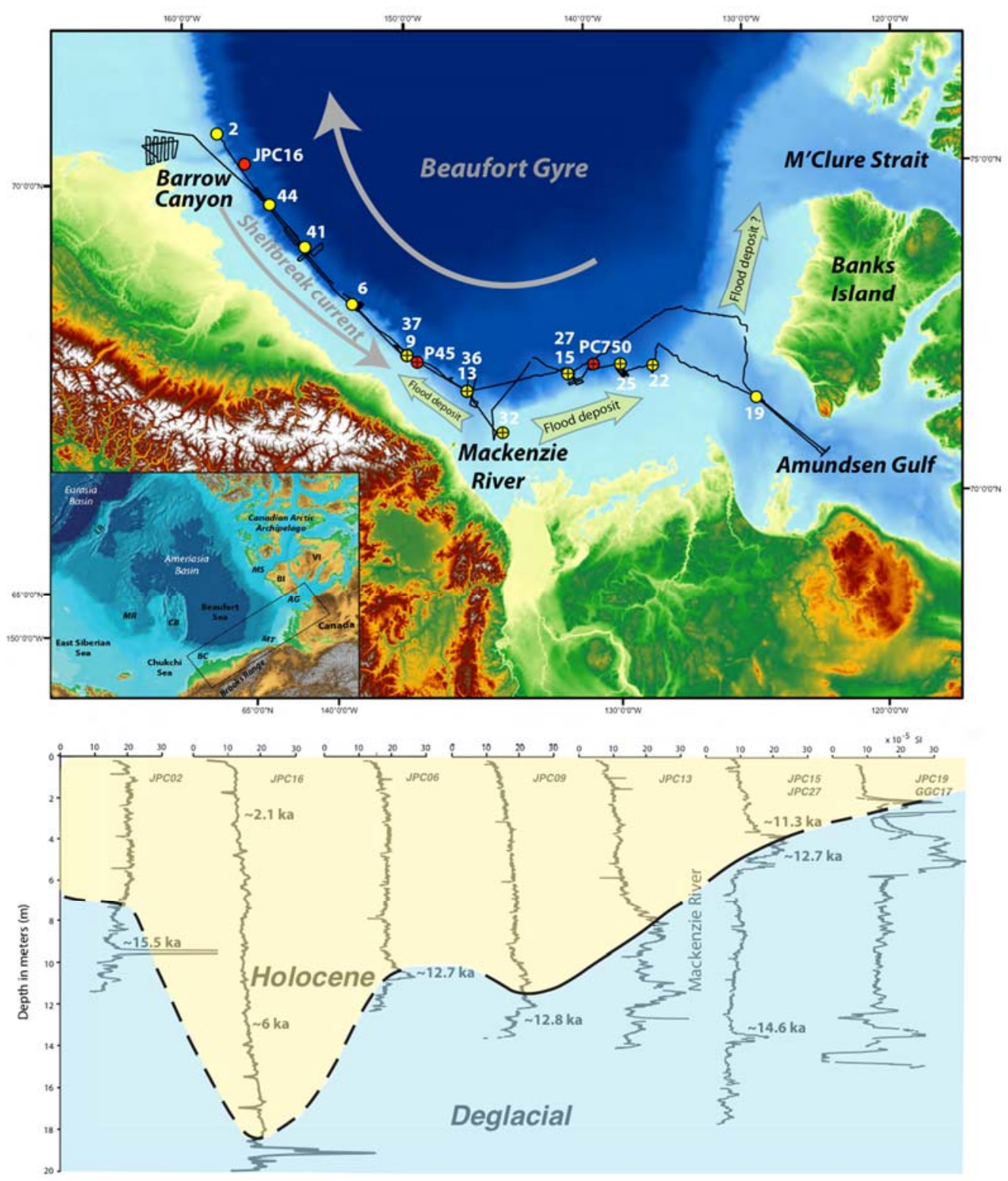

468 Figure 1

469

470 


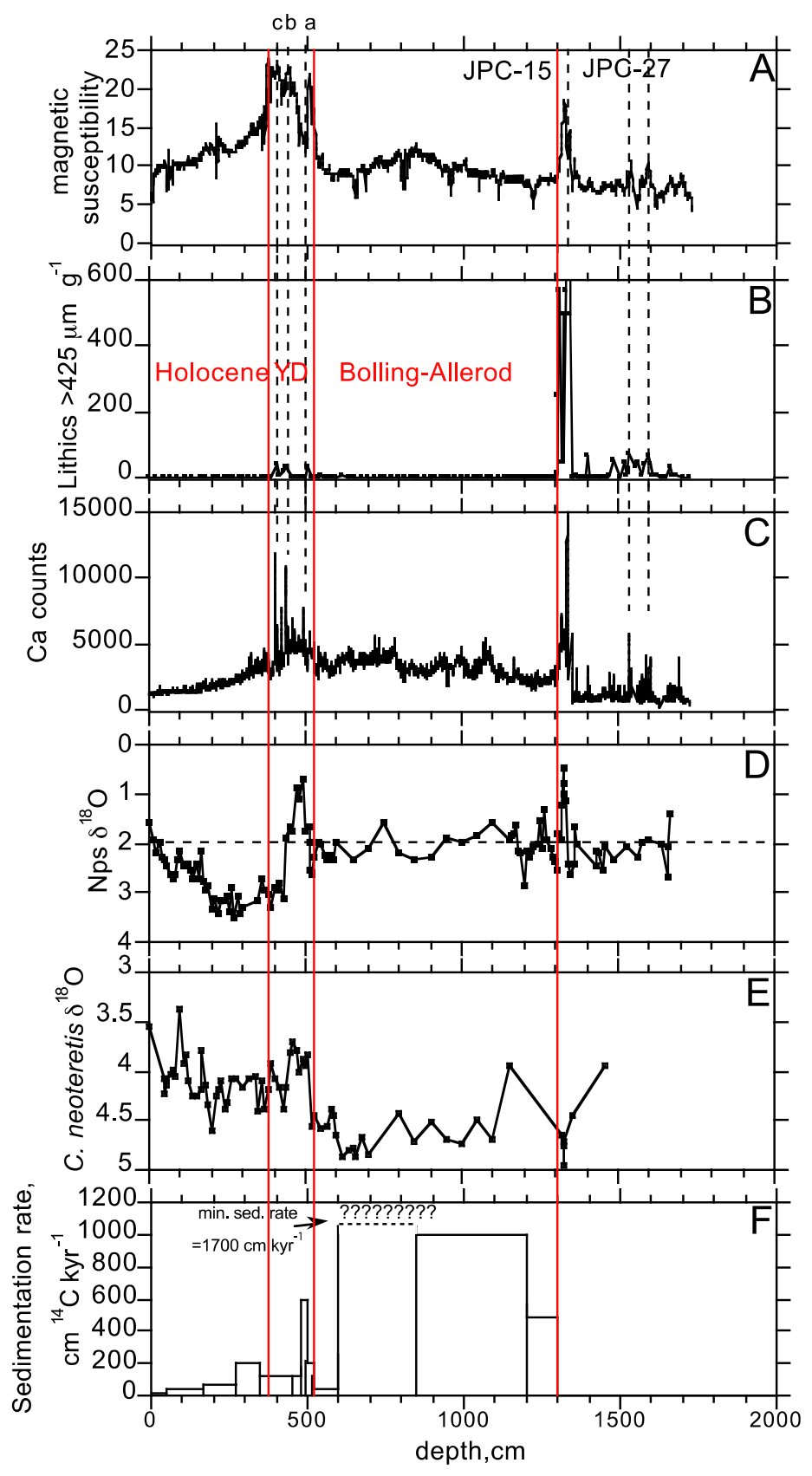

Figure 2 


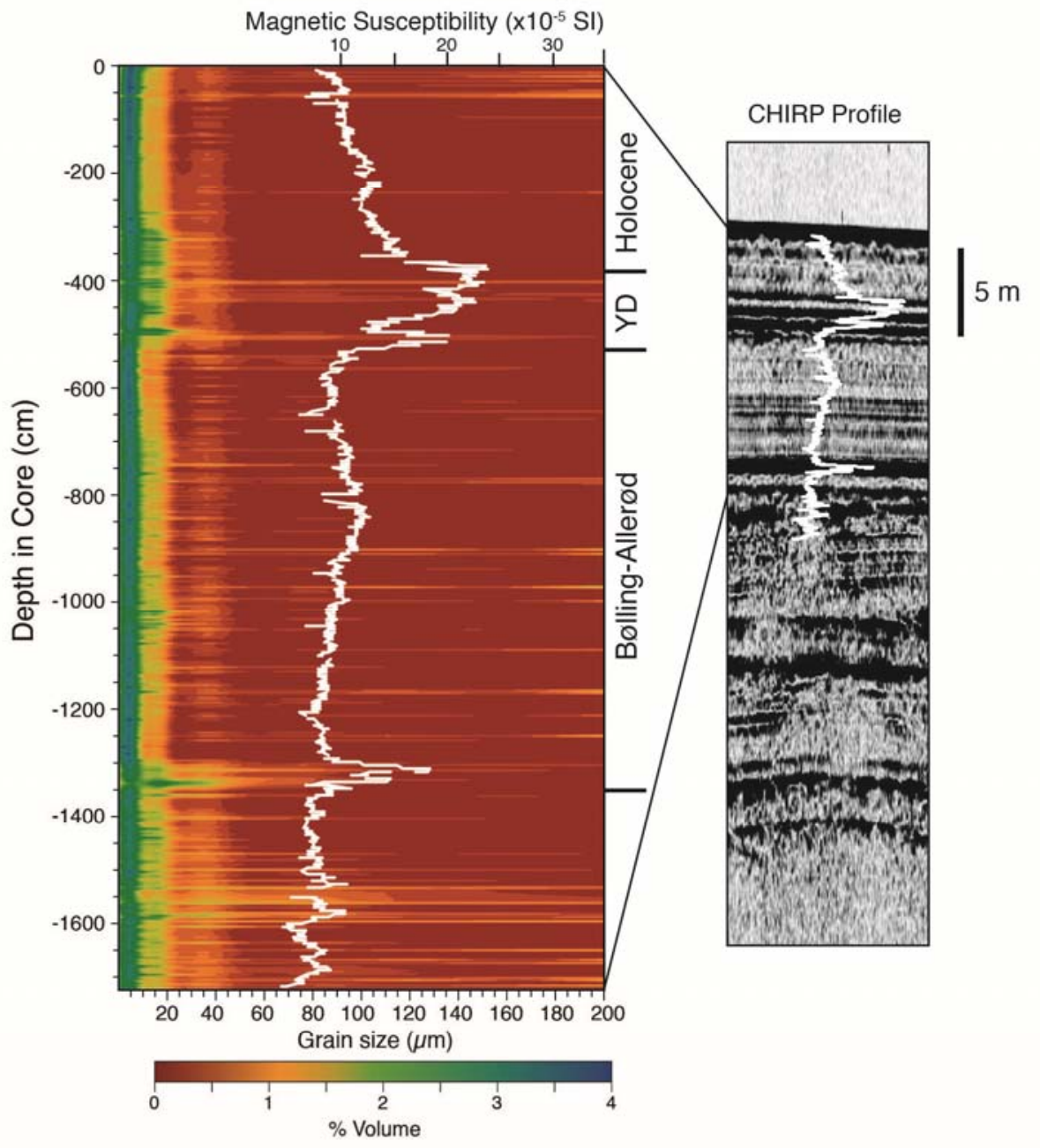

475

476 Figure 3

477 


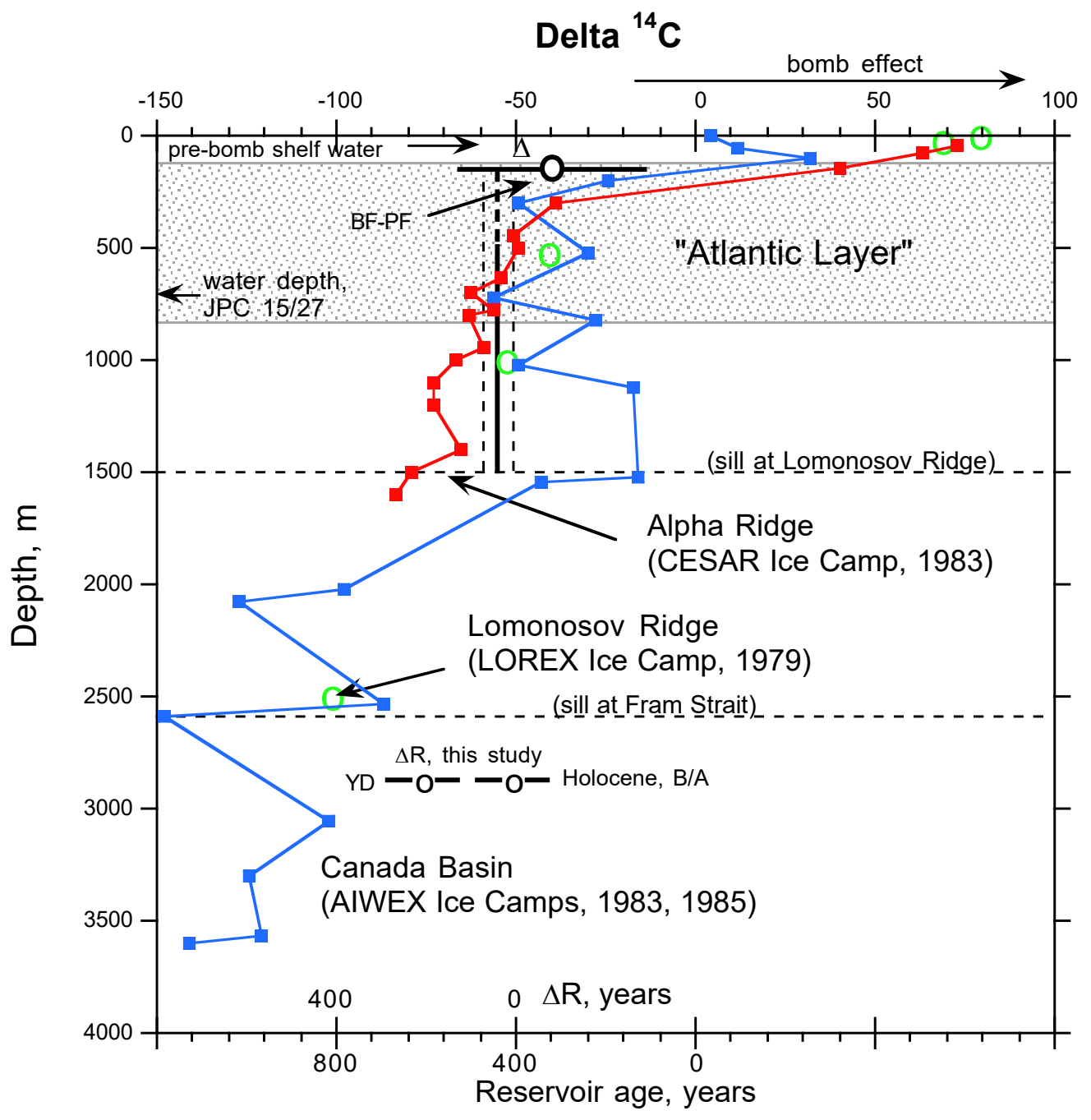

478

479

480 Figure 4

481 


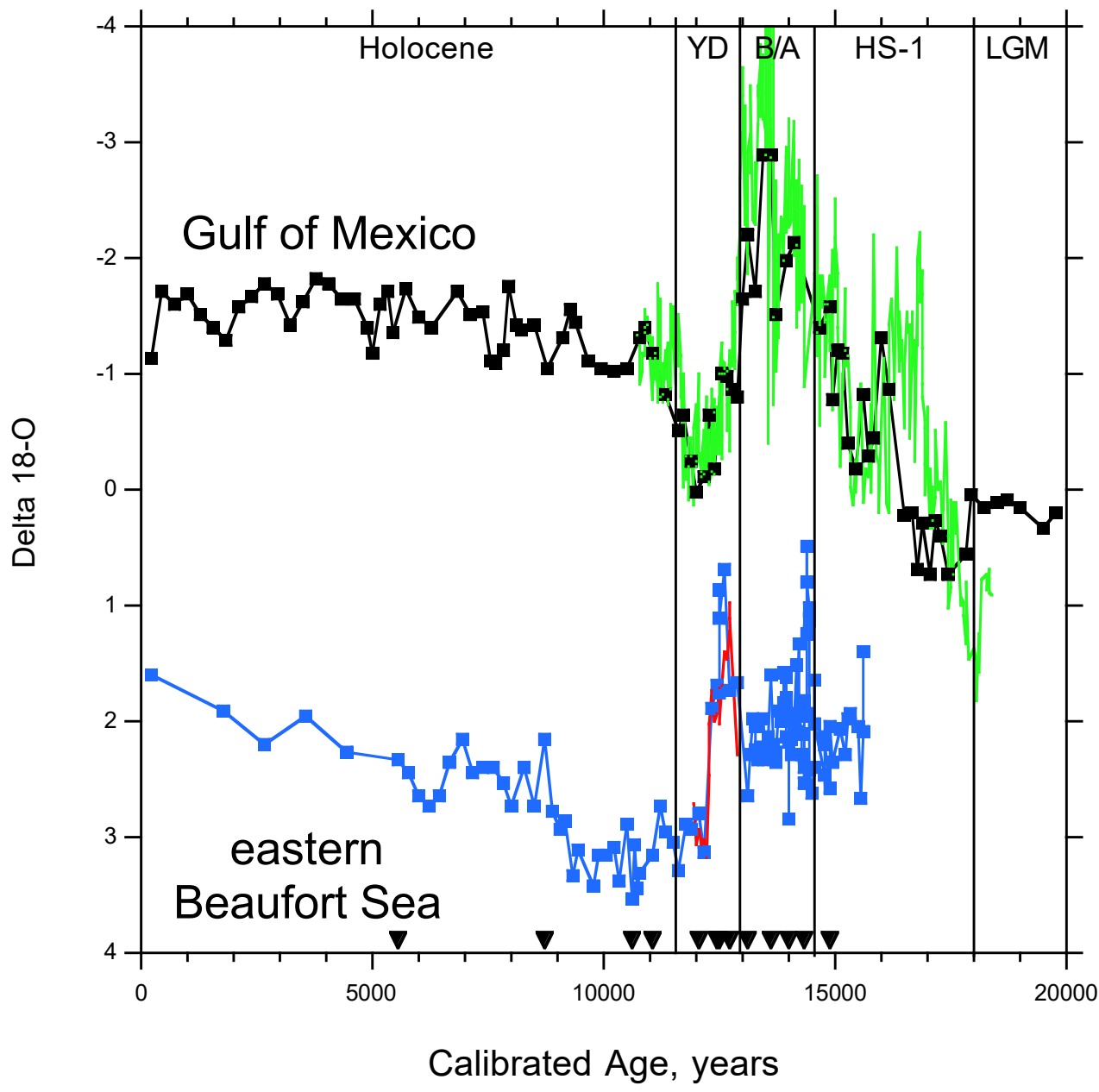

483

484

485

486

Figure 5

\section{Site surveying}

Deglacial Floods in the Beaufort Sea Preceded Younger Dryas Cooling

Supplementary Information

\section{Extended Data}

Sites were surveyed on USCGC Healy using the hull mounted multibeam swath bathymetry system, and a Knudsen 320B/R sonar. The Knudsen system, also hull mounted, operates at a central frequency of $3.5 \mathrm{kHz}$ and sweeps between 2 and $6 \mathrm{kHz}$ which makes it "chirp."

\section{Stratigraphy}




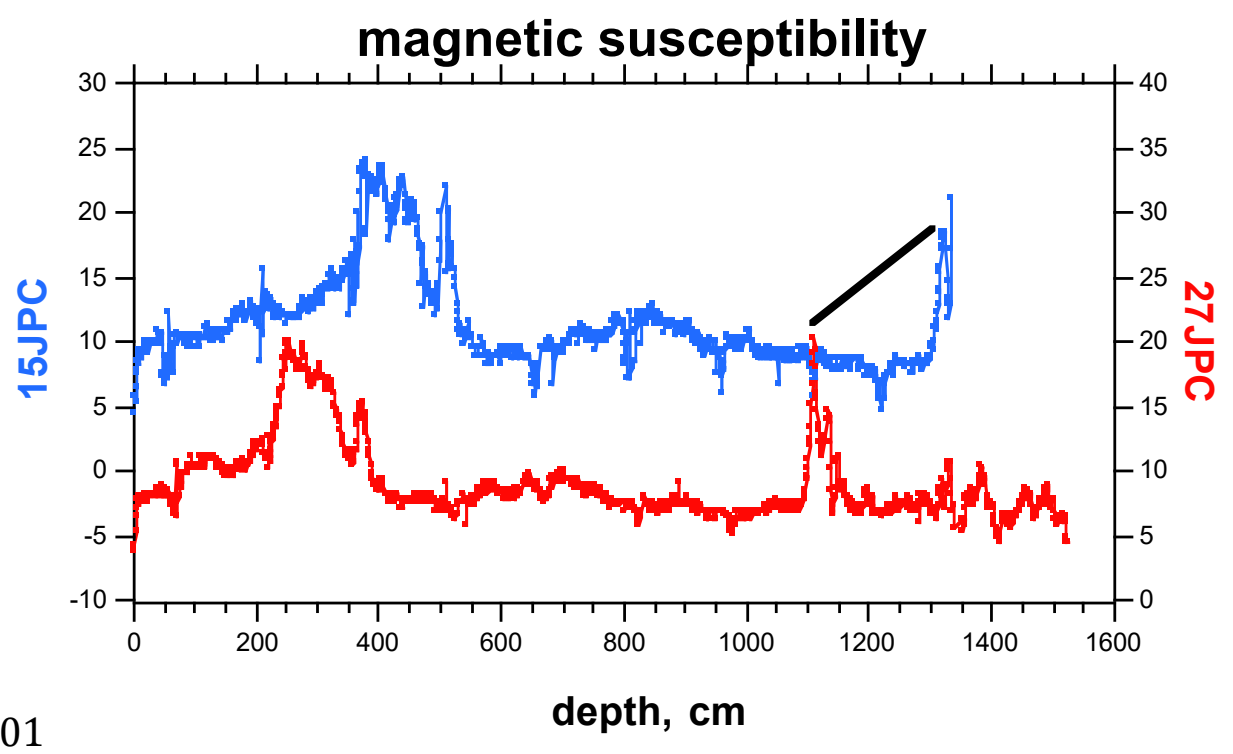

501

Fig. ED1. Magnetic susceptibility records of HLY1302 cores JPC15/2 502 from the same location at $690 \mathrm{~m}$ on the continental slope east of Mackenzje River (JPC15: $71^{\circ} 06.222^{\prime} \mathrm{N}, 1^{\circ} 5^{\circ} 08.129^{\prime} \mathrm{W}$; JPC27: 7106.360’N, 505 $\left.135^{\circ} 09.640^{\prime} \mathrm{W}\right)$. To make a $1729 \mathrm{~cm}$ composite section, we patched to 506 JPC-15 at $1329 \mathrm{~cm}$ the data below $1125 \mathrm{~cm}$ in JPC-27 (with a $+205 \mathrm{~cm} 507$ offset).

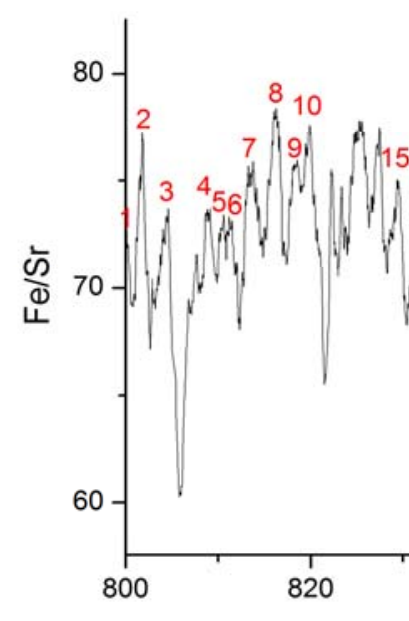

510

511

512

513

514

515

516

517

518
3. Sampling and stable isotopes Core JPC15 was initially chosen for study because of its position east of Mackenzie Trough and because of its

\section{9}

Fig. ED2. Laminae counted using $\mathrm{Fe} / \mathrm{Sr}$ variability of a one-meter section in HLY1302 JPC15. Many other elemental pairs show similar variability. High $\mathrm{Fe} / \mathrm{Sr}$ suggests greater terrestrial content. The resolution of the data is $0.4 \mathrm{~mm}$ and the data are smoothed with a 19-point running mean. There are about 50 peaks in this section with $2 \mathrm{~cm} /$ cycle on average, and the number of cycles varies little with counting method. We counted 300 laminae between $600 \mathrm{~cm}(13460 \mathrm{ka})$ and 1201 $\mathrm{cm}(14408 \mathrm{ka})$ where the deposition rate is uniformly high, and those reflect $\sim 300$ oscillations in terrigenous input to the continental slope that are probably not annual (300 laminae/948 years $=0.32$ laminae/yr) unless the age model underestimates the rate of sedimentation. Note that the calendar ages give lower accumulation rates than those using conventional ${ }^{14} \mathrm{C}$ years as in Fig. $2 \mathrm{~F}$. 
519 typical looking magnetic susceptibility. Not knowing what was present, we began with 520 samples $\sim 20 \mathrm{~g}$ dry every $50 \mathrm{~cm}$. Based on early $\delta^{18} \mathrm{O}_{\mathrm{Nps}}$ results, sampling was increased 521 to every $10 \mathrm{~cm}$. About 20 clean and clear (not infilled) specimens of Nps were chosen

522 for stable isotope measurements using standard methods ${ }^{55}$. Although the focus of the 523 stable isotopes in this paper is $\delta^{18} \mathrm{O}, \delta^{13} \mathrm{C}$ was measured and is reported in Table ED2.

524 Note that the $\delta^{13} \mathrm{C}$ data are featureless for both Nps and C. neoteretis. They compare well

525 with the $\delta^{13} \mathrm{C}$ of dissolved inorganic carbon reported from the eastern Beaufort Sea ${ }^{56}$.

526

527

528

529

530

531

532

533

534

535

536

537

538

539

540

541

542

543

544

545

546

547

4. Chronology

4.1 Gulf of Mexico

Leventer et al. ${ }^{54}$ was the first study to improve on the original Kennett and Shackleton ${ }^{4} \delta^{18} \mathrm{O}$ data with a new higher resolution series from piston core EN32 PC6 in anoxic Orca Basin and with bulk organic ${ }^{14} \mathrm{C}$ dates. That was before AMS dating, so as the interest in meltwater diversion and the origin of the YD grew in the 1980s, Broecker et al. ${ }^{9,57}$ used AMS methods to redate the core. Unfortunately, their results contained substantial age reversals. We include Leventer et al ${ }^{54}$ data in Figure 5 because they provide a Holocene context for the higher resolution and better dated $\delta^{18} \mathrm{O}$ series of Williams et al. ${ }^{5}$. The two data sets are in good agreement where they overlap. However, this was achieved by (selective) use of the available AMS dates at 29.5, 436.5, 471.0, 486.5, and $809 \mathrm{~cm}$ (refs 9, 57) and calibration using $\Delta \mathrm{R}=0$.

\subsection{Beaufort Sea}

Levels for AMS dating (at NOSAMS) were identified based on the $\delta^{18} \mathrm{O}_{\mathrm{Nps}}$ results, and resampled so that as much as $80 \mathrm{~g}$ dry were picked to get sufficient Nps. Where possible, only clean specimens of Nps and C. neoteretis were selected from the size fraction $>150 \mu \mathrm{m}$. This was easy for $C$. neoteretis because the test is transparent, but for Nps we set aside clean and empty specimens and cleaned the remainder mechanically as described elsewhere ${ }^{58}$. If that did not clean them sufficiently, we cleaned them

548 ultrasonically, always setting aside clean ones at each step. Ultrasonic cleaning broke up

549 most tests, but clean fragments were sometimes selected for inclusion in the dated

550 sample. Our chronology is based on a Bayesian age model (Figure ED6) using the Nps

551 dated levels (Table ED1, Fig. ED3). 


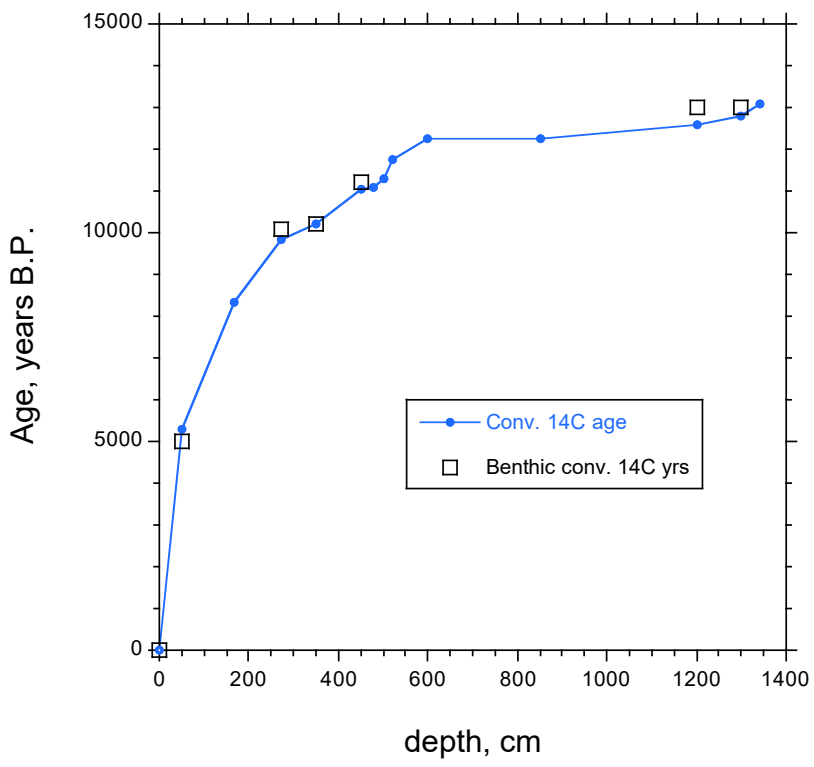

Fig. ED3. Age-depth relationship of conventional AMS ${ }^{14} \mathrm{C}$ dates on $\mathrm{Nps}$ (blue circles) and C. neoteretis (open black squares) from JPC-15.

\subsection{Choice of $\Delta R$}

Any discussion of $\Delta \mathrm{R}$ should begin with the modern, or better yet, the pre-bomb tracers for Arctic processes ${ }^{30,59}$ (Fig. 5), and in pre-bomb museum specimens of mollusks

560 (especially bivalves ${ }^{60}$ ). These are very different data sets and the resulting $\Delta \mathrm{Rs}$ are not directly comparable because the mollusk data came from specimens collected along the nearshore continental shelf whereas the ice station data (and our core sites) are far offshore. One notable thing about the Ostlund et al. ${ }^{30}$ analysis is discussion of the ${ }^{14} \mathrm{C}$ measurement on surface waters in the east Greenland Current in 1957 that leads them to "safely assume" that shelf water had a pre-bomb $\Delta^{14} \mathrm{C}$ of $-48 \pm 3 \%$. (These data were published first by Fonselius and Ostlund ${ }^{61}$ before international standardization.) Although east Greenland is about as far as you can get in the Arctic from the Beaufort Sea, Ostlund and $\mathrm{Hut}^{59}$ showed that the residence time of shelf and near surface waters in the Arctic is only $\sim 10$ years. However, they had no shelf water data from the west Arctic where there 


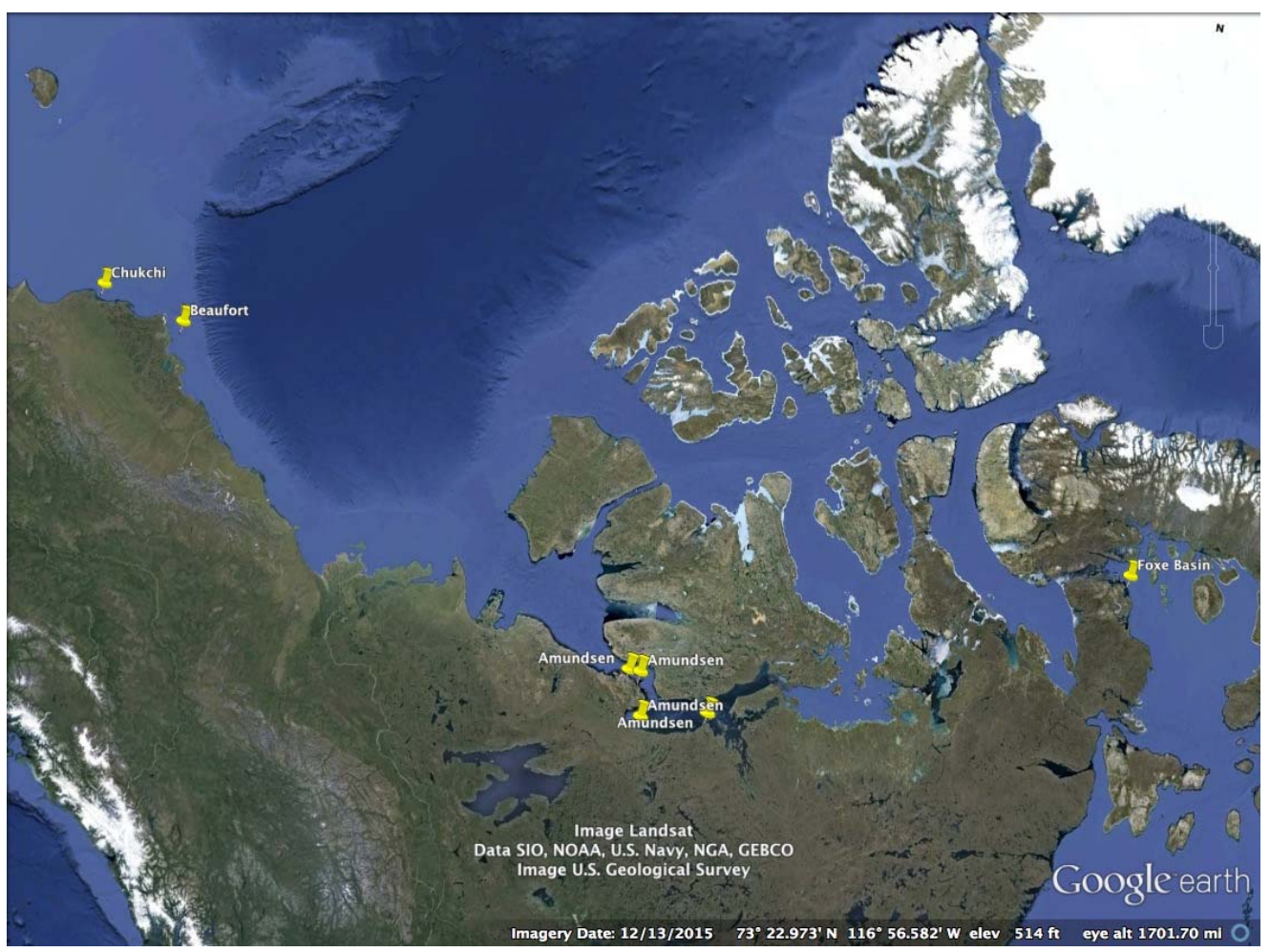

Fig. ED4. Locations of pre-bomb bivalve data ${ }^{60}$ from off Alaska on left, downstream in the Amundsen Gulf (middle), and far to the east in Foxe Basin. These sites were chosen to define a flow path where Bering Strait water always hugs the coast and turns right. Today the shelfbreak current has been traced to the entrance of Amundsen Gulf ${ }^{36}$, but the bivalve ${ }^{14} \mathrm{C}$ data have a Pacific signature as far to the east as northern Foxe Basin.

is low "preformed" $\Delta^{14} \mathrm{C}$ from the Pacific, based on the bivalves. specific purpose of knowing $\Delta \mathrm{R}$ at continental shelf depths. In the Beaufort-Chukchi Seas they reported dates on 7 bivalve specimens collected from two stations (Fig. ED4). Six bivalves were suspension feeders and one was a deposit feeder; that one is significantly older than the others $(\Delta \mathrm{R}=610 \mathrm{yrs})$. Excluding that datum, the others have a mean $\Delta \mathrm{R}$ of $440 \pm 101 \mathrm{yrs}$, or a mean $\Delta^{14} \mathrm{C}$ close to $-100 \%$. That result is greatly different than the $\Delta^{14} \mathrm{C}$ of $-48 \%$ directly measured in in East Greenland shelf waters ${ }^{30}$. The missing element in the Ostlund and $\mathrm{Hut}^{59}$ and Ostlund et al. ${ }^{30}$ analysis was a source of relatively old waters from the NE Pacific via the Alaska Coastal Current and, through Bering Strait, to the shelf break current in the Beaufort Sea. The shelf break current can be traced as far east as Amundsen Gulf, by which point it is dissipated without evidence of entering the $\mathrm{Gulf}^{36}$, but the pre-bomb mollusk data ${ }^{60}$ can be used to trace transport to the Labrador Sea through the Canadian archipelago in recent times. Forty $\Delta^{14} \mathrm{C}$ measurements of Pacific mollusks (Victoria, $\mathrm{BC}$ to Bering Strait), excluding deposit feeders, average $\Delta \mathrm{R}=388 \pm 86 \mathrm{yrs}$, not significantly different from the Chukchi/Beaufort value cited above ( $440 \pm 101 \mathrm{yrs})$. By Amundsen Gulf, where 
McNeely et al ${ }^{60}$ have 7 observations from 5 sites (Fig. ED4), the result, $\Delta \mathrm{R}=350 \pm 116$, is within uncertainty of the Bering Strait source waters. However, by Foxe Basin, $\Delta R=286$ \pm 74 yrs $(\mathrm{n}=8)$, significantly lower (younger) than the Beaufort/Bering Strait data. We choose Foxe Basin as an end point because it represents a pathway that is least likely to encounter younger Atlantic shelf waters, and for the same reason we only use those data on the south side of the strait that connects Gulf of Boothia to Foxe Basin. Nevertheless, a trend of increasing $\Delta^{14} \mathrm{C}$ in pre-bomb mollusks from the Gulf of Alaska to Foxe Basin suggests mixing with a young North Atlantic component. These data are substantially older than the East Greenland mollusks, where $\Delta \mathrm{R}=92 \pm 67$ years $(\mathrm{n}=12)$. measured in both shelf waters (-48 $\pm 3 \%$ ) and in mollusks $(-61 \pm 7 \%$ ), and with results in reasonable agreement. However, this does not mean that shelf $\Delta \mathrm{R}$ should be used to calibrate ${ }^{14} \mathrm{C}$ ages from foraminifera on the Beaufort continental slope for a few reasons. (1) The shelfbreak waters that carry the old signal from Bering Strait are well inshore of the surface water overlying our core sites ${ }^{36}$. (2) Although we do not know the pre-bomb ${ }^{14} \mathrm{C}$ age of Beaufort Sea surface waters (Fig. 4), the rather close agreement of paired benthic and planktonic ${ }^{14} \mathrm{C}$ ages suggests the planktonics live in water influenced by the Atlantic layer even in the Holocene. During pre-Holocene time (>11 ka), before Bering Strait was flooded ${ }^{26,27}$, the Atlantic layer might have shoaled in the absence of Pacific water, all else being equal (pers. comm. 2016 from R. Pickart and M. Spall). However, most importantly, (3) the absence of old Pacific water in the pre-Holocene Arctic means that shelf waters must have had much lower $\Delta \mathrm{R}$ than today prior to 11 or $12 \mathrm{ka}$.

\section{B. $\Delta \mathbf{R}$ in the Nordic Seas}

There are no data from the western Arctic Ocean that can be used to estimate $\Delta R$, so we turn to the Nordic Seas where waters feeding the Arctic surface circulation flow northward along the coast of Norway, and southward from Fram Strait along the Greenland coast to the Labrador Sea. The only useful data sets for this come from Bondevik et al. ${ }^{28}$ and Cao et al. ${ }^{29}$. Cao et al ${ }^{29}$ synthesized existing ${ }^{14} \mathrm{C}$ data from the high latitude North Atlantic and presented new data on solitary corals from Orphan Knoll (1600 $\mathrm{m}$ water depth). They concluded that the Allerod warm period had a $\Delta \mathrm{R}$ similar to today ( $\sim 0$ years), and that $\Delta \mathrm{R}$ was likely about 200 yrs greater during the $\mathrm{YD}$. The Bondevik et al. ${ }^{28}$ data contributed greatly to that conclusion. Orphan Knoll data do not reflect coastal conditions but rather the ventilation of the central Labrador Sea, with an unknown transit time from the surface to $\sim 1600 \mathrm{~m}$.

Accordingly, we base our surface reservoir corrections for the eastern Beaufort Sea on the Bondevik et al. ${ }^{28}$ data for samples where pairs of marine and terrestrial (atmospheric) ${ }^{14} \mathrm{C}$ dates came from within $1-\mathrm{cm}$ of each other in their cores, and not including data the authors rejected as coming from out-of-place fossils. The difference in conventional ${ }^{14} \mathrm{C}$ age between the marine and terrestrial data is defined as $\Delta \mathrm{R}$, and terrestrial dates have been recalibrated using Calib 7.1 using the Marine 2013 curve. 


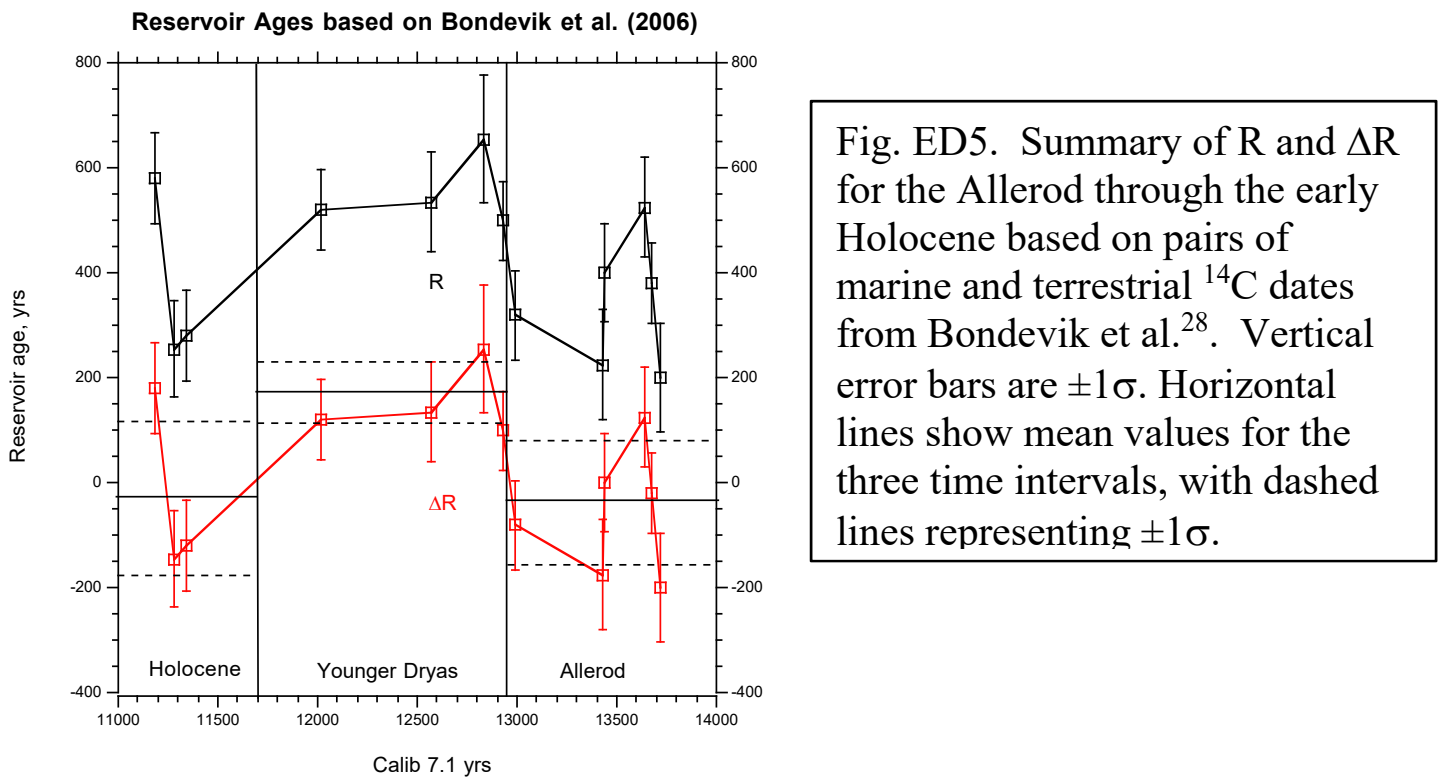

630

631

632

633

634

635

636

637

638

639

640

641

642

643

644

645

646

647

648

649

650

651

652

653

654

655

656

657

658

659

For the Allerod there are seven marine-terrestrial pairs of AMS dates ${ }^{28}$ that return a mean of $-36 \pm 116$ years $(1 \sigma)$ (Figure ED5). For the Younger Dryas and Holocene, the statistics are $170 \pm 60(n=3)$ and $-28 \pm 148(n=3)$, respectively. Although these data essentially come from only one location and are highly variable, they are the only dates that meet our requirement of being in the flow of coastal waters either entering or leaving the Nordic Seas. The low Allerod and higher YD $\Delta \mathrm{R}$ are consistent with the synthesis of Cao et al. ${ }^{29}$ and it makes sense that, during that relatively warm period with better North Atlantic ventilation, the reservoir effect would have been similar to the Holocene. The Holocene results are generally concordant with the pre-bomb estimate of Ostlund ${ }^{30}$. For calibration purposes we chose $\Delta \mathrm{R}=0 \pm 100$ years for the Holocene and the Allerod, and $200 \pm 100$ for the YD. These values are increased somewhat from the measured values (Fig. ED5) because there is some evidence for increased $\Delta \mathrm{R}$ with latitude along the Norwegian coast, but even the authors who made that observation do not agree about its significance $^{62}$. Note that for dating the beginning of the YD it is important to use the Allerod $\Delta \mathrm{R}$, not that of the YD. This is because if the YD flood caused a decrease in the $\mathrm{AMOC}$, and if that caused the increase in $\Delta \mathrm{R}$ through changes in storage and exchange in the ocean-atmosphere carbon system, then the Allerod $\Delta \mathrm{R}$ is more appropriate than the $\mathrm{YD} \Delta \mathrm{R}$.

\subsection{Bayesian age modeling.}

As recommended by an anonymous reviewer, we developed an age model for JPC15/27 using the "Bacon" software of Blaauw and Christen ${ }^{63}$ (2011). This method evaluates rates of sedimentation for discrete sections of the core, and these are informed by results in surrounding sections. The appropriate command settings for our model are: Bacon("JPC-15", 25, acc.mean=2, acc. shape=1.1, normal=TRUE, remember=FALSE, depths.file=T), agedepth(rotate.axes=TRUE, rev.yr=TRUE). We input our ${ }^{14} \mathrm{C}$ dates with the higher $\Delta \mathrm{R}$ during the $\mathrm{YD}$, we fixed the core top to equal zero years, and the calibration was done using the Marine 13 curve. The resulting age-depth relationship (Fig. ED6), illustrates the mean age of levels in the core and the 95\% confidence interval. 
660 Of critical importance is the calendar age of the sample at $514 \mathrm{~cm}$, where $\delta^{18} \mathrm{O}$ is about 661 halfway to its minimum value: 12,939 calendar years B.P., with a minimum age of 66212,786 years and a maximum age of 13,080 years, or about $12.94 \pm 0.15 \mathrm{ka}$. The abrupt 663 decrease in $\delta^{18} \mathrm{O}$ lies within the $95 \%$ confidence interval of $13 \mathrm{ka}$, the nominal date for 664 the diversion of meltwater from the Gulf of Mexico ${ }^{5}$, and before the $\sim 12,850$ year start of 665 the YD on the Greenland ice core timescale ${ }^{34}$.

666 We experimented with other age models, to test the robustness of our result.

667 Using a constant $\Delta \mathrm{R}$ of $0 \pm 100$ yrs for the entire record gave about the same age for the 668 sample at $514 \mathrm{~cm}$ with the variable $\Delta \mathrm{R}$ model, so we know that the "bacon" age is not 669 influenced by the decrease of sedimentation rate and increase in $\triangle \mathrm{R}$ during the YD.

670 Likewise, doubling the uncertainty in $\Delta \mathrm{R}$ for the entire record returns the same ages but 671 with less confidence. In sum, our conclusions are driven mostly by the choice of $\Delta \mathrm{R}$; we 672 cannot reject the hypothesis that the flood down Mackenzie River was coincident with 673 the beginning of the Younger Dryas cooling using any DR that is consistent with the 674 Allerod data (Fig. ED5). Using our preferred age model (Fig. ED6), we summarize ages 675 and uncertainties associated with the $\delta^{18} \mathrm{O}_{\mathrm{Nps}}$ evidence for the YD flood in JPC15/27 in 676 Table ED3.

677 


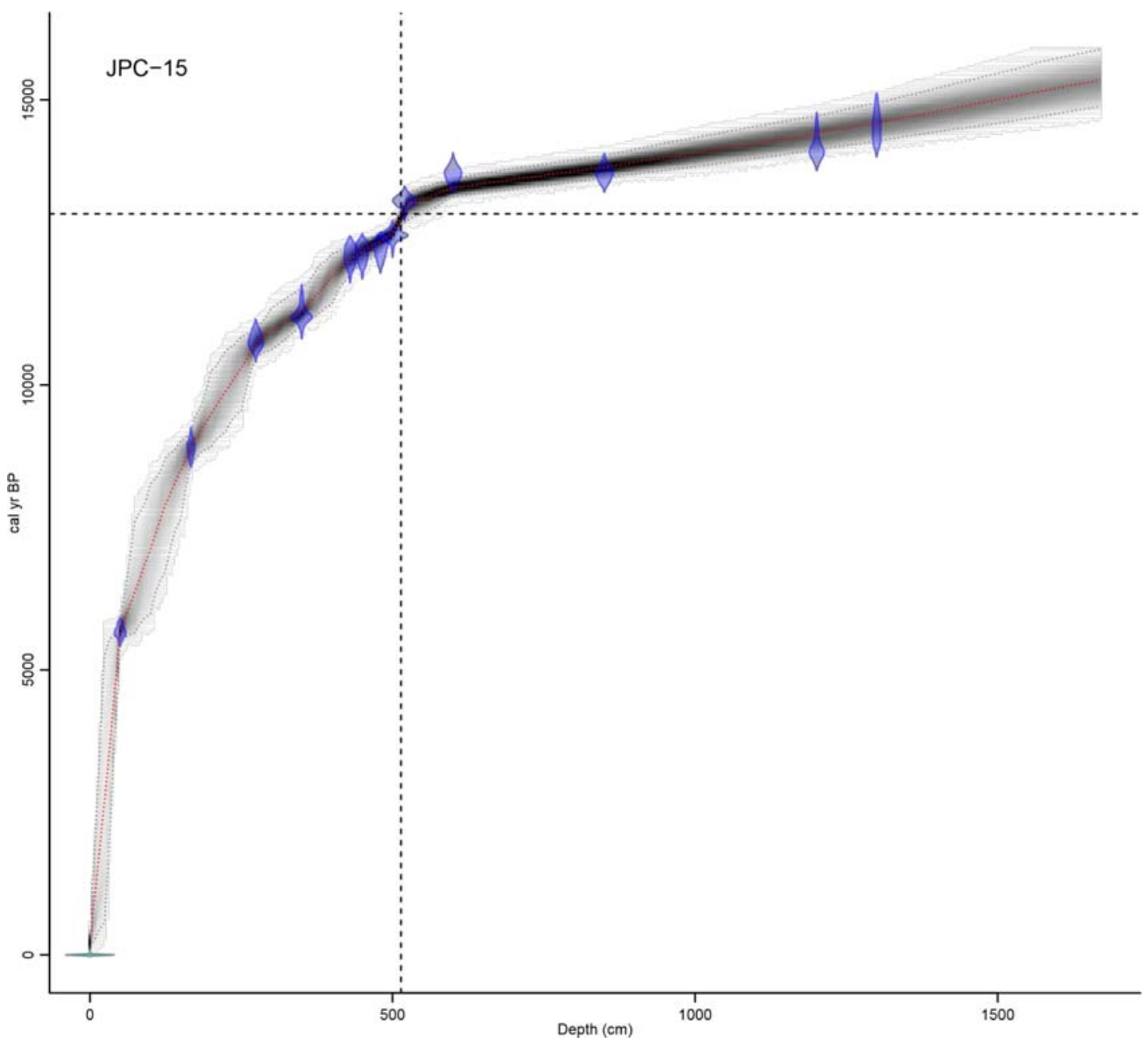

Figure ED6. Age model for JPC15/27 using the Bayesian method "Bacon"63. Horizontal dashed line is at $13 \mathrm{ka}$ and vertical dashed line is at $514 \mathrm{~cm}$. The model gives an age at $514 \mathrm{~cm}$ of $12.94 \pm 0.15 \mathrm{ka}$. A blow-up of the critical $\delta^{18} 0_{\text {Nps }}$ data 12-13.5 ka is shown in Figure ED7.

\section{Regional summary of oxygen isotope data}

\subsection{New core data from this study}

It is important to determine the spatial extent of the YD flood within the Beaufort Sea because Coriolis forcing would drive a buoyant flow to the right from Mackenzie River, and northward along the Canadian Archipelago toward Fram Strait. Such a direct path to the North Atlantic might have the most climate impact because the surface waters would be freshest. On the other hand, wind forcing could counteract the Coriolis driven 


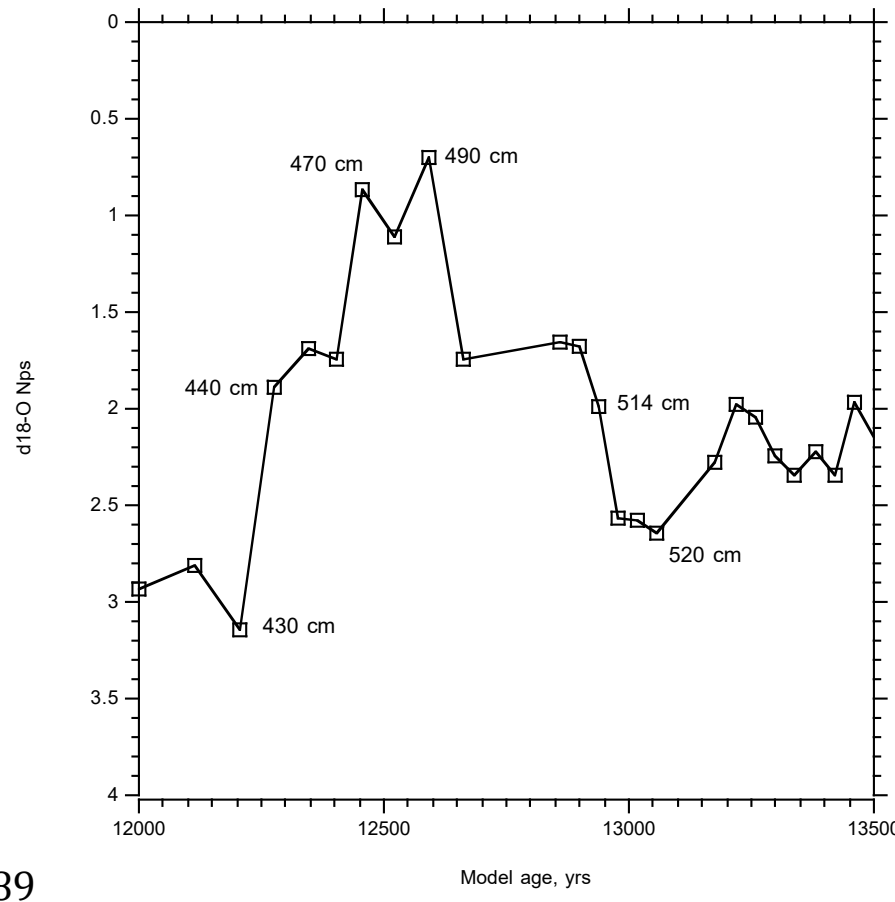

ED Fig. 7. Blow-up of $\delta^{18} \mathrm{O}_{\mathrm{Nps}}$ data associated with the YD flood at JPC15/27. The depth of important features is indicated for reference to ED Table 3. We interpret these data to mean that the flood was underway as early as $12940 \pm 150$ years ago, the age of the sample at $514 \mathrm{~cm}$.

691

692

693

694

695

696

697

698

699

700

701

702

703

704

705

706

707

708

709

710

711

712

713

714

flow and perhaps allow more mixing with Beaufort Gyre. In that case, the freshening in the North Atlantic region might have been less but may have lasted longer.

Here we summarize the stratigraphic data from cores extending from JPC15/27 in the east, which we consider to be a "type section," to other cores as far west as Barrow, AK (Fig. ED8). West of Mackenzie River at JPC-09 we have identified a $\delta^{18} \mathrm{O}_{\mathrm{Nps}}$ minimum at about $13 \mathrm{~m}$ below the seafloor. It reaches $1 \%$, close to the minimum at JPC15/27 and it occurs a meter below a prominent maximum in magnetic susceptibility. This phasing is similar to results at JPC15/27, and the AMS date at JPC-09 falls within the range of dates constraining the flood event to the east. The brief peak in magnetic susceptibility at JPC15/27 at $\sim 500 \mathrm{~cm}$ is not matched at JPC-09 probably because the ice rafting, which becomes common $>1300 \mathrm{~cm}$, stopped the corer. If we calibrate the YD ${ }^{14} \mathrm{C}$ ages from JPC-09 (Table ED1) with $\Delta \mathrm{R}=200 \pm 100$, the $\delta^{18} \mathrm{O}_{\mathrm{Nps}}$ changes are wellmatched at the two cores (Fig. 5, Fig. ED9).

JPC-09 is very close to core P45 of Andrews and Dunhill (2004)(Fig. 1), so we recalibrated the age model for that core using $\Delta \mathrm{R}=0 \pm 100$ (post YD) and plotted their $\delta^{18} \mathrm{O}_{\mathrm{Nps}}$ with the new data from this study (Fig. ED9). The agreement between these cores is good, although the age model may make the bottom of P45 too old because their oldest date was on benthic foraminifera. Note that the minimum in $\delta^{18} \mathrm{ONps}_{\mathrm{N}}$ was not found by Andrews and Dunhill (2004), most likely because the corer failed to penetrate the ice rafted layer at about $5 \mathrm{~m}$ subbottom.

Continuing farther west of Mackenzie River, the $\delta^{18} \mathrm{O}_{\mathrm{Nps}}$ at JPC-06 records only a small minimum before the main peak in magnetic susceptibility (Fig. ED8). This suggests that the YD meltwater plume must have been very localized to the region east of this site with only minor salinity lowering of the near surface ocean. Of the samples

715 examined, a small peak in ice rafting is associated with the small minimum in $\delta^{18} \mathrm{O}_{\mathrm{Nps}}$. 


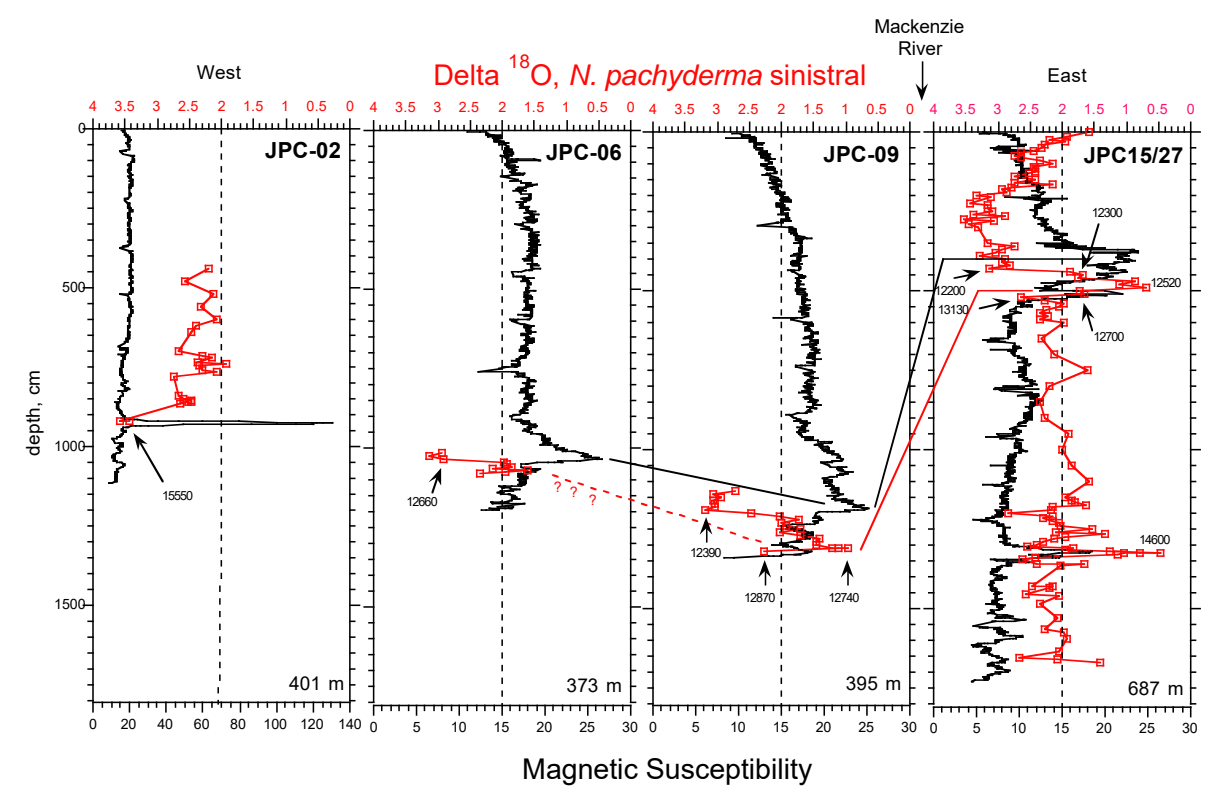

716

717

Figure ED8. Comparison of magnetic susceptibility and $\delta^{18} \mathrm{O}_{\mathrm{Nps}}$ stratigraphies in a zonal transect of cores from east of Mackenzie River (JPC15/27) to Barrow, $\mathrm{AK}$ (JPC-02). The vertical dashed line in each core marks the baseline $\delta^{18} \mathrm{O}_{\mathrm{Nps}}$ as reference for surface freshening. The solid black and red lines correlate the magnetic susceptibility $\delta^{18} \mathrm{O}_{\mathrm{Nps}}$ peaks, respectively. Note the decreasing influence of $\delta^{18} \mathrm{O}_{\mathrm{Nps}}$ lowering (freshening) from east to west.

718

719

720

721

722

723

724

725

726

727

728

729

730

731

732

733

734

735

736

In the Chukchi Sea off Barrow, AK, the most notable feature of JPC-02 is an IRD and magnetic susceptibility peak at $\sim 920 \mathrm{~cm}$ that dates to 15.55 calibrated ka and includes a 6-cm dark non-carbonate dropstone. Because this event is not recorded far to the east at JPC15/27, and is $>1000$ years older than the $14.6 \mathrm{ka}$ event at that site, it gives a maximum age for the bottom of the composite section at JPC15/27, assuming the event came from the Canadian Archipelago and would probably have spread across the Beaufort Sea. That maximum age $(15.5 \mathrm{ka})$ agrees well with the $15.4 \mathrm{ka}$ extrapolated age for the end of the JPC $15 / 27 \delta^{18} \mathrm{ONps}_{\mathrm{N}}$. Also of note is the maximum in $\delta^{18} \mathrm{O}_{\mathrm{Nps}}$ coincident with this IRD layer; this is the opposite of what we see in the YD and 14.6 ka events closer to Mackenzie River and it is the heaviest we have measured in this study.

Most of the $\delta^{18} \mathrm{O}_{\mathrm{Nps}}$ data fall higher than the $2 \%$ reference level for the entire record $<15.5 \mathrm{ka}$ (Fig. ED8), similar to the nearby Holocene results from Keigwin et al. ${ }^{26}$. Thus, taking into account the ice volume effect on $\delta^{18} \mathrm{O}$, we conclude that the near sea surface off Barrow was fresher than today during most of the deglaciation, but there must also have been a salinity gradient from the Chukchi Sea to the eastern Beaufort Sea. This points to Mackenzie River as the source of the freshening, but the absence of evidence for the YD flood off Barrow suggests that floodwaters were not diluted much by mixing in the Beaufort Gyre. If supported by further data, this could mean that the YD flood was 


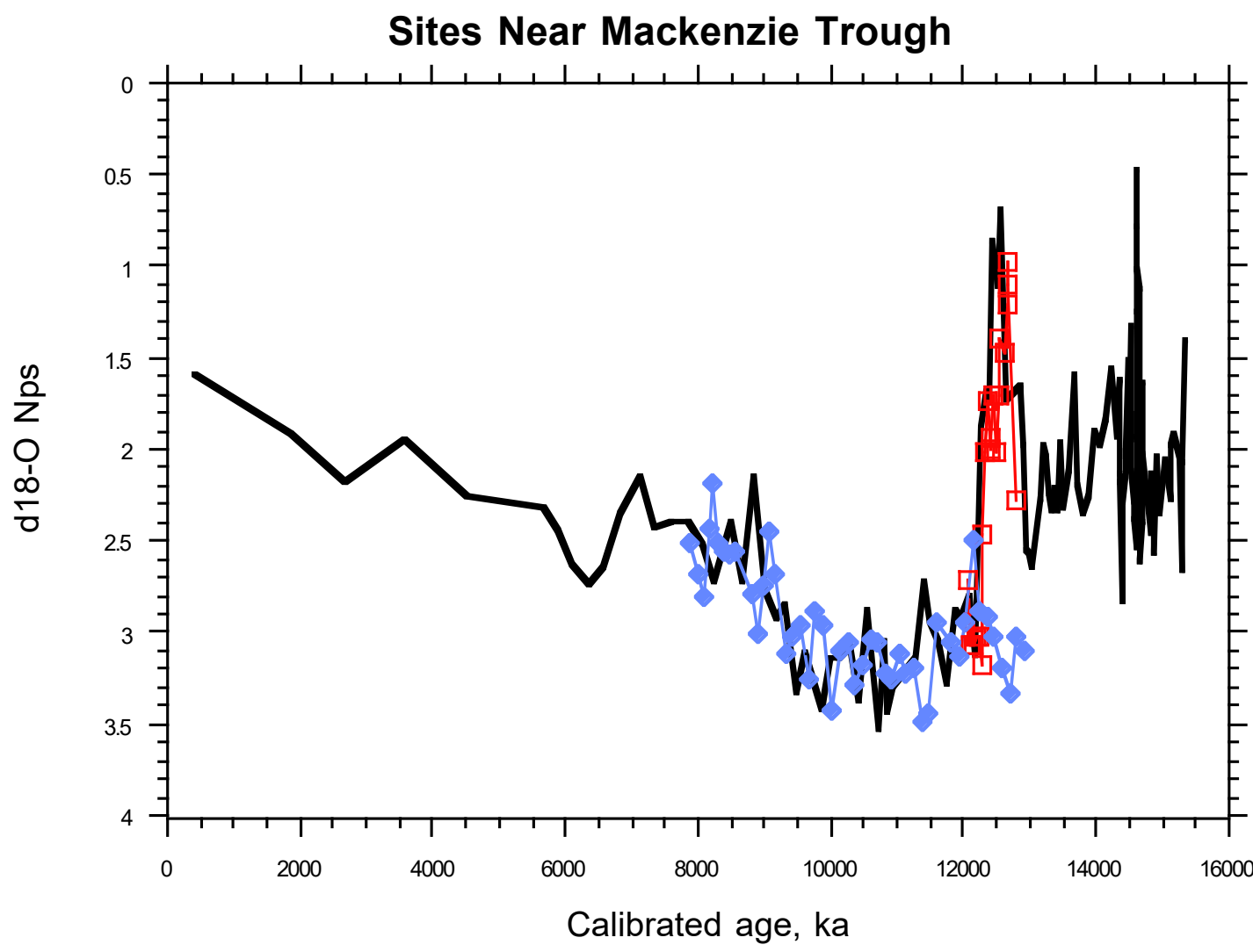

Fig. ED9. Comparison of $\delta^{18} \mathrm{O}_{\mathrm{Nps}}$ data between JPC15/27 (black line), JPC-09 (red squares) and core P45 (blue diamonds) ${ }^{64}$. Note the excellent agreement of minima in $\delta^{18} \mathrm{O}_{\mathrm{Nps}}$ from this study.

\subsection{Other published core data}

Several papers report stable isotope and radiocarbon data from the western Arctic (Mendeleyev Ridge) including, for example, Poore et al. ${ }^{65}$ and Polyak et al. ${ }^{66}$. We cannot directly correlate our results from the eastern Beaufort Sea with those because they have much lower rates of sedimentation and fewer ${ }^{14} \mathrm{C}$ dates. Given that we also cannot correlate to our own core off Barrow (Fig. ED8), which does have high rates, it is possible that there was substantial spatial variability in near surface ocean conditions in the western Arctic during deglaciation. As an example of this, both Poore et al. ${ }^{65}$ and Polyak et al. ${ }^{66}$ found deglacial minima in $\delta^{18} \mathrm{O}_{\mathrm{Nps}}$ that are $0 \%$ or even lower. These are probably not evidence of the YD flood from Mackenzie River because the $\delta^{18} \mathrm{O}_{\mathrm{Nps}}$ is lower than we observe closer to the source, and the rates of sedimentation are probably too low to resolve such a brief event.

Closer to the Beaufort Sea, on the Chukchi Borderlands, Polyak et al. ${ }^{67}$ do find a $\delta^{18} \mathrm{O}_{\mathrm{Nps}}$ minimum of about $1 \%$ that could be related to one of those we see at core $15 / 27$. 
However, using $\Delta \mathrm{R}=0$, their benthic foram calibrated date for that event is $13.8 \mathrm{ka}$ which falls between the events we have found. That event is associated with a small peak in ice rafting (but not magnetic susceptibility), and below that there is a much larger undated IRD event coincident with a large peak in magnetic susceptibility.

In addition to the comparisons discussed above, we can also correlate to results from Mackenzie Trough near our JPC-13 (ref. 41). One of their cores sampled the same high $\delta^{18} \mathrm{O}_{\mathrm{Nps}}(3.11 \pm 0.28 \%, \mathrm{n}=9)$ interval $\sim 10-12 \mathrm{ka}$ as in JPC15/27. The Schell et al. ${ }^{41}$ data fall mostly between 10.9 and $10.6 \mathrm{ka}$ when recalibrated.

\section{Extended Data references:}

55. Keigwin, L.D. Radiocarbon and stable isotope constraints on last glacial maximum and Younger Dryas ventilation in th western North Atlantic. Paleoceanography 19, doi: 10.1029/2004PA001029 (2004).

56. Oxtoby, L.E., Mathis, J.T., Juranek, L. W. \& Wooller, M. .J. Estimating stable carbon isotope values of microphytobenthos in the Arctic for application to food web studies. Polar Biol. 39, 473-483 (2016).

57. Broecker, W.S. et al. Acclerator mass spectrometric radiocarbon measurments on foraminifera shells from deep sea cores. Radiocarbon 32,119-133 (1990).

58. Keigwin, L.D. \& Lehman, S.J. Radiocarbon evidence for a benthic front near $3.1 \mathrm{~km}$ in the Equatorial Pacific Ocean. Earth Planet. Sci. Lett. doi: /10.1016/j.epsl.2015.05.025 (2015).

59. Ostlund, H. G. \& Hut, G. Arctic Ocean water mass balance from isotope data. Jour. Geophys. Research 89, 6373-6381 (1984).

60. McNeely, R., Dyke, A. S. \& Southon, J. Canadian marine reservoir ages preliminary data assessment. Geological Survey of Canada open file 5049: DOI: 10.13140/13142.13141.11461.16649 (2006).

61. Fonselius, S. \& Ostlund, G. Natural radiocarbon measurements on surface water from the North Atlantic and the Arctic Sea. Tellus 11, 77-82 (1959).

62. Mangerud, J. Bondevik, S., Gulliksen, S., Hufthammer, A.K. \& Hoisaeter, T. Marine ${ }^{14} \mathrm{C}$ reservoir ages for $19^{\text {th }}$ century whales and molluscs from the North Atlantic. Quaternary Science Reviews 25, 3228-3245 (2006).

63. Blaauw, M, \& Christen, J. A. Flexible paleoclimate age-depth models using an autoregressive gamma process Bayesian Analysis 6, 457-474 (2011).

64. Andrews, J. T. \& Dunhill, G. Early to mid-Holocene Atlantic water influx and deglacial meltwater events, Beaufort Sea slope, Arctic Ocean. Quaternary Res. 61, 14-21 (2004).

65. Poore, R. Z., Osterman, L., Curry, W. B. \& Phillips, R. L. Late Pleistocene and Holocene meltwater events in the western Arctic Ocean. Geology 27, 759-762 (1999).

66. Polyak, L., Curry, W. B., Darby, D.A., Bischof, J. \& Cronin, T. M. Contrasting glacial/interglacial regimes in the western Arctic Ocean as exemplified by a sedimentary record from the Mendeleev Ridge. Palaeogeo., Palaeoclim., Palaeoeco. 203, 73-93 (2004). 
800

801

802

803

$\$ 04$

805

806

807

808

809

810

\section{ED Appendix 1.}

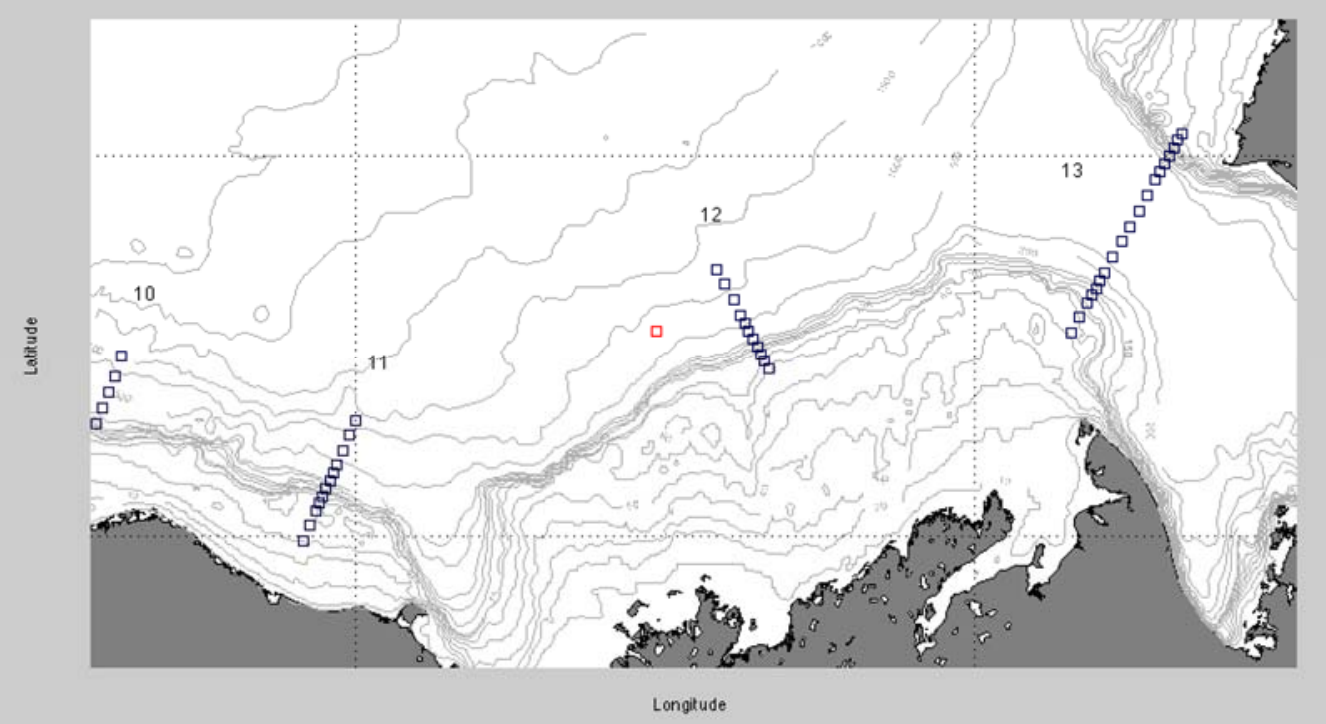

ED Appendix Fig. 1. HLY1003 Station positions for the hydrographic data in ED Appendix Fig. 2 provided by Dr. Robert Pickart (WHOI). The position of HLY core JPC15/27 is shown as a red square.

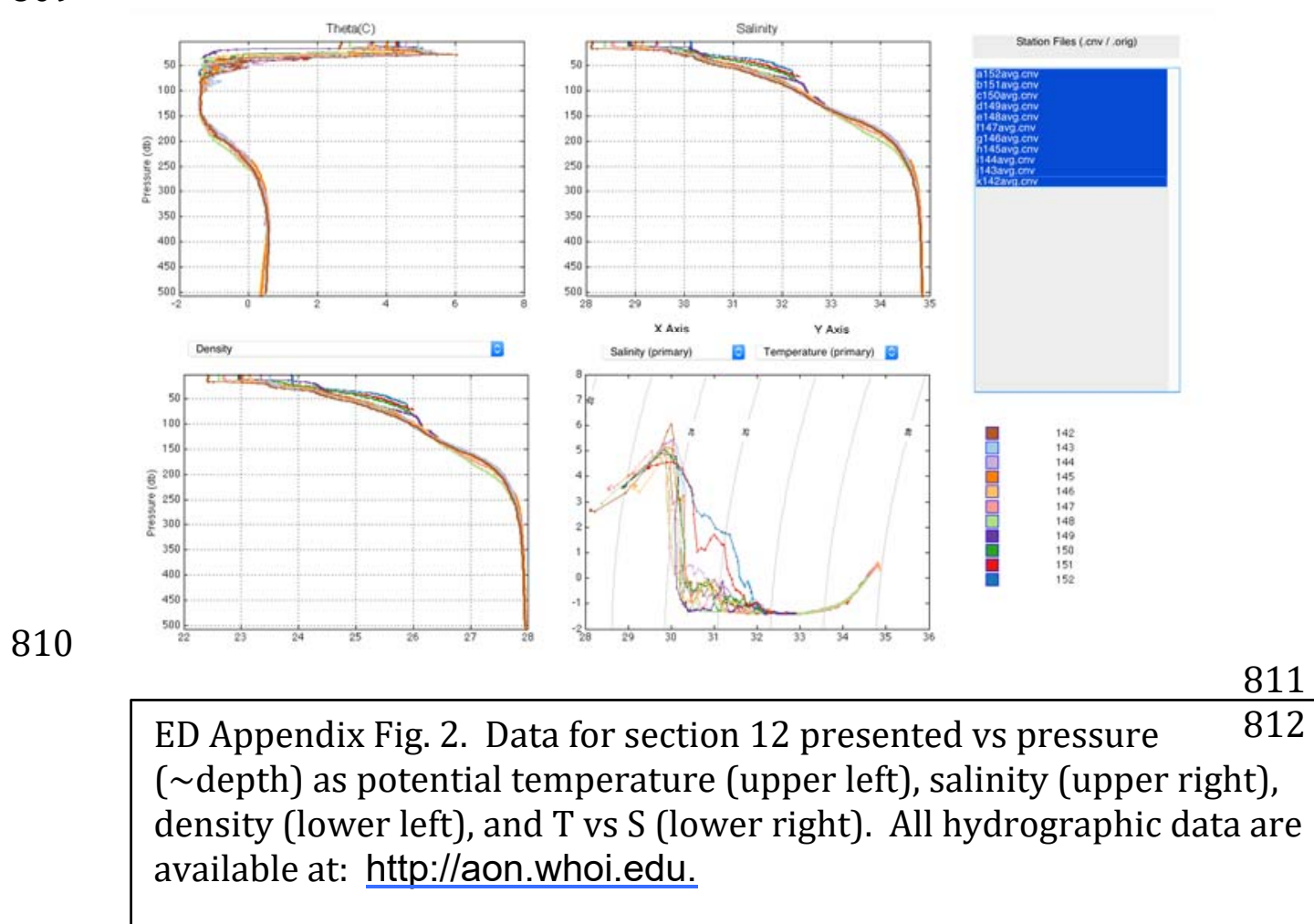

